\title{
BOWLING FOR FASCISM: SOCIAL CAPITAL AND THE RISE OF THE NAZI PARTY IN WeIMAR GERMANY, 1919-33
}

\author{
Shanker Satyanath Nico Voigtländer Hans-Joachim Voth \\ NYU UCLA and NBER UPF, CREI, and \\ CEPR
}

\begin{abstract}
Social capital - a dense network of associations facilitating cooperation within a community - typically leads to positive political and economic outcomes, as demonstrated by a large literature following Putnam. A growing literature emphasizes the potentially "dark side" of social capital. This paper examines the role of social capital in the downfall of democracy in interwar Germany by analyzing Nazi party entry rates in a cross-section of towns and cities. Before the Nazi Party's triumphs at the ballot box, it built an extensive organizational structure, becoming a mass movement with nearly a million members by early 1933 . We show that dense networks of civic associations such as bowling clubs, animal breeder associations, or choirs facilitated the rise of the Nazi Party. The effects are large: Towns with one standard deviation higher association density saw at least one-third faster growth in the strength of the Nazi Party. IV results based on $19^{\text {th }}$ century measures of social capital reinforce our conclusions. In addition, all types of associations - veteran associations and non-military clubs, "bridging" and "bonding" associations - positively predict NS party entry. These results suggest that social capital in Weimar Germany aided the rise of the Nazi movement that ultimately destroyed Germany's first democracy.
\end{abstract}




\section{Introduction}

Social capital - a dense network of civic associations - goes hand in hand with a host of benign outcomes. ${ }^{1}$ Alexis de Tocqueville saw it as a basis of vigorous democracy; similarly, Putnam finds that it creates more trust, social cohesion, and political participation. Social capital also predicts positive development outcomes. ${ }^{2}$ Where it is plentiful, GDP per capita is higher, and financial markets are more developed (Knack and Keefer 1997; Dasgupta and Serageldin 2000; Grootaert and Bastelaer 2002). Guiso, Sapienza, and Zingales (2008) point to the deep historical roots of civil society; citizens in Italian cities that were selfgoverning in the Middle Ages are today richer, participate more in elections, and engage more in pro-social behavior such as blood donations. ${ }^{3}$

At the same time, there are good theoretical reasons why social capital could have negative effects. ${ }^{4}$ In their survey, Durlauf and Fafchamps (2004) concluded that "the creation of clubs may ... reinforce polarization in society between the 'in' group and the 'out' group". Putnam (2000) distinguishes between bridging and bonding social capital, and accepts that only the former is unambiguously positive. More generally, co-operation of in-group members has been shown to facilitate criminal activities (Field 2003). Recently, the role of social capital in

\footnotetext{
${ }^{1}$ Durlauf and Fafchamps (2004) conclude that "[t]he study of social capital is that of networkbased processes that generate beneficial outcomes through norms and trust".

2 Putnam and Goss (2002) conclude that "communities endowed with a diverse stock of social networks and civic associations are in a stronger position to confront poverty and vulnerability, resolve disputes, and take advantage of new opportunities."

${ }^{3}$ Costa and Kahn (2007)found that social connections are a significant predictor of survival in prisoner of war camps; social capital is also essential for the efficiency of military units (Creveld 1982; Costa and Kahn 2008).

4 Putnam's (1995) Bowling Alone contains a chapter on the "dark side of social capital" that acknowledges some of these ambiguities.
} 
entrenching ruling elites in the developing world has received attention (Acemoglu, Reed, and Robinson 2013).

What is missing in the emerging literature on the "dark side" of social capital is clear-cut evidence that a functioning democracy itself can be undermined as a result of having a rich network of clubs and associations. This paper demonstrates that the rise of the Nazi Party in interwar Germany was more rapid where a dense network of civic associations facilitated the spread of its message. Germany before and after World War I was home to a vigorous civil society clubs for singing, bowling, shooting, hiking, and animal-breeding were everywhere, absorbing a significant share of citizens' spare time (Nipperdey 1976). Using new, hand-collected data from interwar city directories from municipal archives and city libraries, we examine the speed of Nazi mobilization as a function of the density of civic associations. In a cross-section of German towns and cities, association density is strongly and positively correlated with entry into the NSDAP.

Rates of entry into the Nazi Party matter because the organizational strengthening of the party during the 1920s long preceded its spectacular electoral successes. A large membership basis was arguably one of the crucial ingredients in the party's rise in the polls. The party's tightly-controlled organization composed of thousands of local "cells" in the majority of German cities underpinned success in national elections (Brustein 1998). In 1928, for example, the party received only $2.6 \%$ of the national vote; at the same time, it 
already had 100,000 party members in some 1,400 local chapters (Anheier 2003). ${ }^{5}$ In turn, the NSDAP's growing popular and electoral support ultimately led to the fall of the German's first democracy. By undermining the Weimar Republic and facilitating the creation of a powerful extremist movement, dense social networks in interwar Germany ultimately contributed to the rise of a singularly murderous regime.

We argue that associations facilitated recruitment for anti-system parties, by helping to spread pro-Nazi messages. This is in line with substantial historical evidence on the rise of the Nazi movement and the role played by pre-existing local networks in attracting new members. ${ }^{6}$ Party entry is the main focus of our empirical analysis. Figure 1 summarizes the basic pattern in the data: in towns and cities with a denser network of clubs and associations, many more Germans entered the Nazi Party (as a percentage of the population). We group locations into terciles based on association density, and then calculate NS entry rates. The higher association density, the more rapidly citizens joined the ranks of the Nazi Party. The differences in the proportion entering the party are substantial - for cities in the highest tercile of association density, the average entry rate per 1,000 for the period as a whole was 10.7; in the lowest, it was only 5.9/1,000 - 45 percent lower.

\footnotetext{
${ }^{5}$ By 1930, the relationship between membership figures and voting results changed dramatically - the party grew to 129,000 members, while it surged at the polls to $18.3 \%$ of the vote.

${ }^{6}$ We summarize this literature in more detail below.
} 


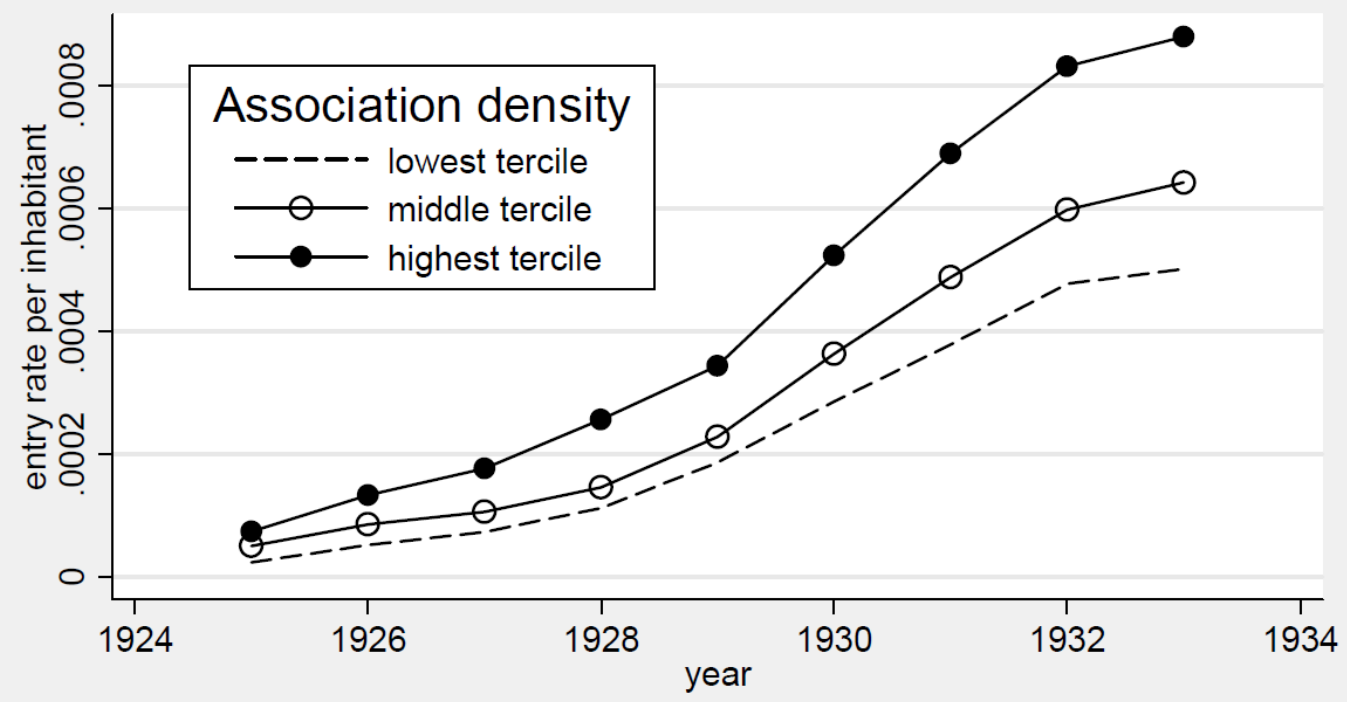

Figure 1: Cumulative NSDAP membership, by tercile of association density

The basic pattern is confirmed in cross-sectional regressions where we control for a range of socio-economic characteristics. We also show that these results are robust to a wide range of alternative specifications and group definitions. Some associations were explicitly anti-democratic and militaristic, such as the numerous veteran associations. Could the spread of the Nazi Party and the density of associations simply measure the same underlying preferences, namely a wide-spread authoritarian culture? We examine this question by first excluding all associations with a political angle, such as the front soldier clubs. Even when using only the density of the remaining associations (overwhelmingly, bowling, singing, hiking, and animal breeding clubs), we obtain the same result - the Nazi Party spread more rapidly in the fabric of German society where citizens had more points of social contact outside the workplace.

To shed more light on the observed effects, we use an IV-strategy based on deeper historical roots of local group formation. We use two instruments to 
predict civic association density in the 1920 s - mid-19th century participation in gymnast and singing associations. Gymnast associations ("Turner") were amongst the earliest civic associations with a sizeable following in all of Germany. In addition, we use the number of singers from each city that participated in the 1861 Singer Festival ("Sängerfest") in Nuremberg. Using only the variation reflecting these two historical measures, we show that areas with a greater density of associations were more prone to fall for the lure of the Nazi movement.

While our results suggest a causal link, they are not necessarily conclusive. For example, unobserved local characteristics may be associated with both the formation of associations in the mid-19th century and the rise of the Nazi party in Weimar Germany. To assess the extent to which unobservables may drive our results, we follow Altonji, Elder, and Taber (2005) in calculating how strong selection on unobservables would have to be in order to explain the full observed relationship between association density and Nazi party entry. We find that the impact of unobserved factors would have to be at least 2.5 times stronger, as compared to observed factors, in order to explain away the relationship between associations and Nazi party entry. This makes it unlikely that unobservable factors can account for our results.

Our paper contributes to a large literature on the effects of social capital. Field (2003) summarizes empirical evidence that pre-existing social networks can facilitate crime and the rise of gangs. ${ }^{7}$ For the case of Sierra Leone, Acemoglu,

\footnotetext{
${ }^{7}$ Note that there are counter-examples, which we cannot survey in full here. For example, Susan Saegert and Gary Winkel (2004) found that social capital at the building level in an inner-city sample was negatively associated with participation in crime.
} 
Reed, and Robinson (2013) show that social capital is negatively correlated with governance outcomes - it helps local leaders to become entrenched. Faced with less competition, they deliver fewer public goods. Also, extremist groups - like the Klu Klux Klan - thrive on civic society values, but promote hate (Chambers and Kopstein 2001; Gutmann 1998).

Our work follows earlier historical research on interwar politics in Germany, Italy, and Romania, and the role of social capital in the fall of democracy in these countries. Riley (2005) contrasts the role of civic associations and the rise of fascism in Italy and Spain. In the former, the North - with its denser networks of clubs and societies - saw more fascist cells being founded. In Spain, there was a general paucity of social capital, but there is no clear-cut relationship with support for the Franco regime. In a similar spirit, Welldorfer (2003) examines the rise of fascism in Italy, focusing on election results. In contrast to Riley, he finds that civic society offered some protection from the rise of fascism, but only in certain elections. ${ }^{8}$

Finally, we contribute to the literature on the rise of the Nazi Party. The last six decades have seen a massive production of research seeking to explain the party's success at the polls and as a mass movement. Initial theorizing focused on "isolated members of the masses", marginal loners who - in the Nazi Party finally found a group in which they felt they belonged (Shirer 1960). ${ }^{9}$ An

\footnotetext{
${ }_{8}^{8}$ Neither paper exploits cross-sectional variation in association membership quantitatively to predict entry rates into the fascist party.

${ }^{9}$ Abel (1938) analyzed autobiographical notes of NS members submitted for an essay competition "Why I became a Nazi". He saw a preponderance of rural workers, workers in transport and domestic industry, and middle class members joining for what they describe as ideological motives.
} 
alternative literature interpreted the rise of the Nazi Party as a form of class conflict (Winkler 1987). Our paper is closely related to the research emphasizing group membership, which gained wider currency from the 1970s onwards (Linz 1976). This strand of the literature assigns crucial importance to the "conquest of the bourgeois infrastructure" (Mommsen 1978), i.e., the infiltration of existing high-level national and regional lobbying groups (Verbände) representing farmers and other special interests. Berman (1997) pointed out that Weimar Germany as a whole had an exceptionally high number of civic associations, but that these did little to support the struggling democracy. She argued that social capital may backfire if "frustration with the failures of the national government and political parties" runs high, and concluded that "... had German civil society been weaker, the Nazis would never have been able to capture so many citizens for their cause ..." (Berman 1997). At the same time, she offers no quantitative evidence that the NSDAP spread faster where there were more associations - it is logically possible that Weimar would have collapsed even faster had it not been for rich civic life at the local level. Koshar (1987), in a detailed study of Marburg, demonstrated that NS members were typically active in numerous local groups (Koshar 1986). Anheier (2003) showed how well-connected individuals acted as political entrepreneurs. Using their social connections and professional standing, they attracted new members for the party, leading to the founding of new local chapters. ${ }^{10}$

Relative to the existing literature, we make several contributions. To the best of our knowledge, we are the first to analyze quantitatively social capital's contribution to the eventual fall of democracy, using detailed city-level data on

\footnotetext{
10 The vast literature on voting results for the Nazi Party cannot be surveyed here. Important contributions include (Childers 1983; Hamilton 1982; Falter 1991; King et al. 2008).
} 
the density of associational life and entry rates into a radical party. ${ }^{11}$ Second, we show that the positive association between social capital and the rate of joining an extreme party is not confined to anti-democratic and militaristic associations it is not a simple reflection of pre-existing differences in ideological outlook. Our results are equally strong for bowling, singing, and animal breeding clubs etc. This implies that even "bridging" social capital can have negative effects. Third, we show that scale effects are unlikely to be important - association density affects both early and late party entries with a similar magnitude.

The paper proceeds as follows. Section 2 discusses the historical context and our data. Section 3 presents the main empirical results, and section 4 shows that our results are robust to a wide range of alternative specifications. Section 5 concludes.

\section{Historical context and data}

In this section, we summarize briefly the literature on the social origins of Nazi Party members, as well as research on the role of associations in Germany after 1800. We also describe how our sample of towns with information on association density was selected and how the data was constructed.

\footnotetext{
${ }^{11}$ A few other scholars have demonstrated that social capital can be related to negative outcomes, mostly due to the exclusionary character of many social networks, and with consequences at the local level. See Field 2003 (chapter 3) for a review of this literature.
} 


\section{A. Historical Background}

\section{The Origins of the Nazi Party}

The Nazi Party deliberately aimed to compete with leftwing parties for the mass support, replacing the Communist-inspired ideology of the latter with nationalist and racist ideals (Shirer 1960). From the party's early days, Hitler and his associates emphasized organization-building - in their view, the rise to power would be inevitable if the Nazi Party could successfully turn itself into a mass movement. Initial growth was slow, but eventually, membership figures reached very high levels. From a handful of supporters in 1919, the party grew to 850,000 members in January 1933 - on par with the Social Democratic Party (SPD). ${ }^{12}$

Local chapters (Ortsgruppen) provided the organizational foundation for the Nazi Party's rise in any one location. Under the leadership of a local party leader, the local chapters were in charge of coordinating member activities, recruiting new members, collecting dues, and organizing social, cultural, and political activities. In towns without a local NS chapter, individual members could also join. These "single members" would eventually form the nucleus of an Ortsgruppe (local chapter). Between the national leadership and the local chapters, the so-called Gaue acted as an intermediate administrative level. Germany was divided into 33 (later, 43) Gaue, which had roughly the size of federal states but did not coincide with them.

Who joined the Nazi Party and for what reasons has been the subject of a major research effort. Initial theories emphasized the party's appeal for marginalized

\footnotetext{
${ }^{12}$ Childers (1983). The NS membership figure is also nearly three times higher than Communist membership in 1932.
} 
groups and unrooted individuals; Marxist interpretations emphasized the idea that the petty bourgeoisie - threatened by a possible slide into the proletariat gave overwhelming support to the Nazis (Heiden 1935; Stephan 1931). Quantitative studies were conspicuous by their absence. It was only from the 1970s onwards, when parts of the NS membership master file were computerized, that these predictions could be confronted with data. The central membership registry of the NSDAP survived the war, but only by accident - it was captured by advancing US troops in a paper mill, awaiting destruction. The NS membership master file - consisting of millions of individual member cards was initially held by the American-controlled Berlin Document Center, and was then transferred to the German Federal Archives.

Studies of NS members show that they were indeed overwhelmingly recruited from middle classes (Mittelstand). ${ }^{13}$ In the early years, the party recruited a disproportionate share of members from the upper ranks of the Mittelstand. University students were amongst the first groups to sign up to the Nazi program in large numbers. This could be seen as supporting the hypothesis that the Nazi Party acted was a channel for lower middle-class frustrations and fears of social decline by the petty bourgeoisie. Two reasons speak against this: First, as time went by, NS members were increasingly drawn from the lower ranks of the middle classes (Kater 1983). Blue collar workers were substantially underrepresented relative to the population. In the party's early years (1919-23), only $22.8 \%$ were laborers. This compares with a proportion of $53 \%$ in the Reich as a whole (Madden and Mühlberger 2007). As late as January 1933, the workers' proportion in the party was only $31.5 \%$ (Mühlberger 2003).

${ }_{13}$ This includes artisans, white collar workers, small business owners, professionals in the arts, farmers, managers and senior officials, as well as military officers. 
Second, the over-representation of white collar workers was actually not specific to the NSDAP; even in the Social Democratic Party (SPD) and the Communists (KPD), the educated middle classes constituted a much higher proportion than in the population at large. This in turn suggests that the petty bourgeoisie hypothesis is largely incorrect; the Nazi Party went far beyond the narrow confines of a few classes, and succeeded in becoming a Volkspartei (people's party).

Associations in Germany after 1815

The right to free assembly, and to form associations, was hotly contested after the Restoration of the old political order in 1815. Until 1848, the German territories repressed most forms of bourgeois sociability. Both associations and larger gatherings needed approval by the authorities, which were routinely denied. The gymnast associations - spreading in number and influence during the Napoleonic Wars - were outlawed from 1820 until 1848. Singers' associations never suffered a blanket ban, but were closely watched. The third kind of assocations that grew after 1815 were student fraternities (Burschenschaften). Their members had volunteered in large numbers in the fight against Napoleon. After 1815, they agitated in favor of German unification. Following a political murder, most of the student fraternities were suppressed. ${ }^{14}$ Before 1848, Germany's early associations were both liberal and nationalist in character; they mostly favored the formation of a unified fatherland and an end to the rule by

\footnotetext{
14 The movement split into a political and a non-political branch, and never recovered its wider political significance (Wentzcke 1965).
} 
princes over often tiny territories, as well as parliamentary representation, a charter of rights, and freedom of assembly, speech, and religion. ${ }^{15}$

Both the singing and the gymnast associations contributed to the 1848 revolution, but their exact influence is hard to gauge (Obermann 1963). After the failed revolution, which was closely followed by an end to many of the earlier prohibitions, associations spread throughout the country. At the same time, many of them became increasingly apolitical, focusing on folklore and local traditions (Düding 1984). In addition to the original associations, new ones bringing together budgie breeders, rabbit owners, stamp collectors, and supporters of a plethora of worthy causes mushroomed. Student associations on the other hand became increasingly nationalistic and militarist, and several of them adopted xenophobic and anti-Semitic ideas in the late $19^{\text {th }}$ century (Haupt 1925).

By the interwar period, most associations saw themselves as apolitical - not supporting any particular party or world-view. In the Catholic Rhineland, all ranks of societies often joined Carnival associations, tasked with organizing revelries during the "silly season". While many organizations were explicitly Catholic or Protestant, almost every town and city also had a large number of non-denominational associations (Reichardt 2004). Associations reflected the views and biases of German civic society in general; where politics were not deliberately kept out of the club, there was a society for every political grouping.

\footnotetext{
${ }^{15}$ Vereinsnationalismus (nationalism of the associations) was neither xenophobic nor militaristic; it mainly emphasized the need to unify all Germans in a nation state similar to France and England, where all could interact as equals (Dunn 1979) The liberal nationalism of early $19^{\text {th }}$ century Germany is therefore fundamentally different in nature to the nationalism fostered by the actual unification of the Reich under Bismarck in 1871 (Eley 1980).
} 
Workers' gathered in workmen's singing associations; Communists reminisced about their frontline experiences together; fervent nationalists had their own societies to discuss the fate of Germany's colonies; and enlightened Germans organized a society for reducing anti-Semitism (Zeiss-Horbach 2008; Koshar 1986).

Associations and Party Entry

We argue that towns and cities with denser social networks saw more Nazi party entries. This hypothesis reflects a close reading of the historical record. For example, Koshar (1986) uses the example of Emil Wissner, a salesman in Marburg. He was a member of a white-collar employee association (from 1921), and active in two gymnastics clubs (from 1904). He joined the party in 1929, and actively used his position to proselytize for the party, and to win new members.

Koshar's work shows that new entrants in the Nazi Party in Marburg had on average more association and club memberships than non-joiners - even when we only count non-political associations. Similarly, Anheier (2003) analyzes single members - entrepreneurial NS Party members who did not join through a local chapter, and often established a bridgehead for the movement. They succeeded on a vastly greater scale in founding new party chapters where they had numerous pre-existing affiliations. Single members with four or more civic society connections were 18 times more likely to successfully establishing a local branch of the Nazi Party than those with no connections at all - and still three times more than party members with only one association membership (Anheier 2003). While many of these association memberships were in nationalist 
organizations that shared an ideological base with the Nazi Party, the groups involved clearly went beyond this:

“...the movement may have 'fed' on preexisting membership structures and clusters which the single members helped channel into the reestablished Nazi party. Ties with other 'bourgeois' associations of Germany's civil society may well have enhanced this process by extending the reach of single members for recruitment purposes."

Abel's (1938) analysis of NS member autobiographies reflects that the recruitment efforts of single members succeeded often in a context of pre-existing affiliations. A bank clerk was a member of the youth movement that emphasized outdoor activities, music, and hiking (Wandervogel), ${ }^{16}$ and called it his "personal preparatory school for National Socialism." ${ }^{17}$ After drifting into an anti-Semitic association, he eventually joined the NSDAP. A soldier recounts how after the war, he joined a variety of associations, including the Jungdo18, an "association of nationally minded soldiers", and the Stahlhelm. ${ }^{19}$ Eventually, he joined the Nazi party. Personal interaction with Party members often worked wonders in convincing skeptics. One member recounts how he

“...became acquainted with a colleague of my own age with whom I had frequent conversations. He was a calm, quiet person whom I esteemed very highly. When I found that he was one of the local leaders of the

\footnotetext{
16 The Wandervogel (German for migratory bird) had a strong romanticist and anti-authoritarian bend. While nationalistic in some aspects, it is seen by some as a precursor of the hippie movement. It was outlawed after 1933 (Stachura 1981).

${ }_{17}$ Abel (1938).

${ }^{18}$ A national-liberal youth group, it was anti-monarchist and favored reconciliation with France. The association was also anti-Semitic and elitist (Wolf 1972).

${ }^{19}$ Literally, "steel helmet" - a veterans association with mostly nationalist aims (but not affiliated or allied with the Nazi Party until the very end of the Weimar Republic).
} 
National Socialist party, my opinion of it as a group of criminals changed completely..."

While not every party member was recruited via clubs and associations, it is clear that the Nazi party consciously used pre-existing social networks to spread its influence and gain new members. In those cases where the strategy succeeded, the importance of personal connections and the associated increase in trust is readily apparent. Next, we collect systematic data to test if the microevidence is actually borne out in the cross-section - that more social capital in Weimar Germany spelled a faster rise of the Nazi Party.

\section{Data}

We hand-collected data on association density from a total of 112 German towns and cities on the territory of modern-day Germany. ${ }^{20}$ The sources for information on associations are town and city directories listing "useful contacts", from local banks and service providers such as dentists to local clubs and associations. The main constraint is data survival. Printed and distributed locally, city directories typically only survived in the local city library or archive. We wrote to all towns and cities with a listed archive or public library. Figure 2 gives a sense of the geographical distribution of our sample. Data come from all parts of Germany cities as far North as Kiel and as far South as Konstanz are included; the sample also covers the entire country from East to West.

\footnotetext{
${ }^{20}$ Towns and cities in the formerly German areas of Eastern Europe rarely preserved marginal library holdings such as city directories - and war damage in many of the relevant cities (Königsberg, Breslau) was massive due to protracted urban fighting between the Wehrmacht and the Red Army. We therefore decided to focus on the territory of modern-day Germany.
} 


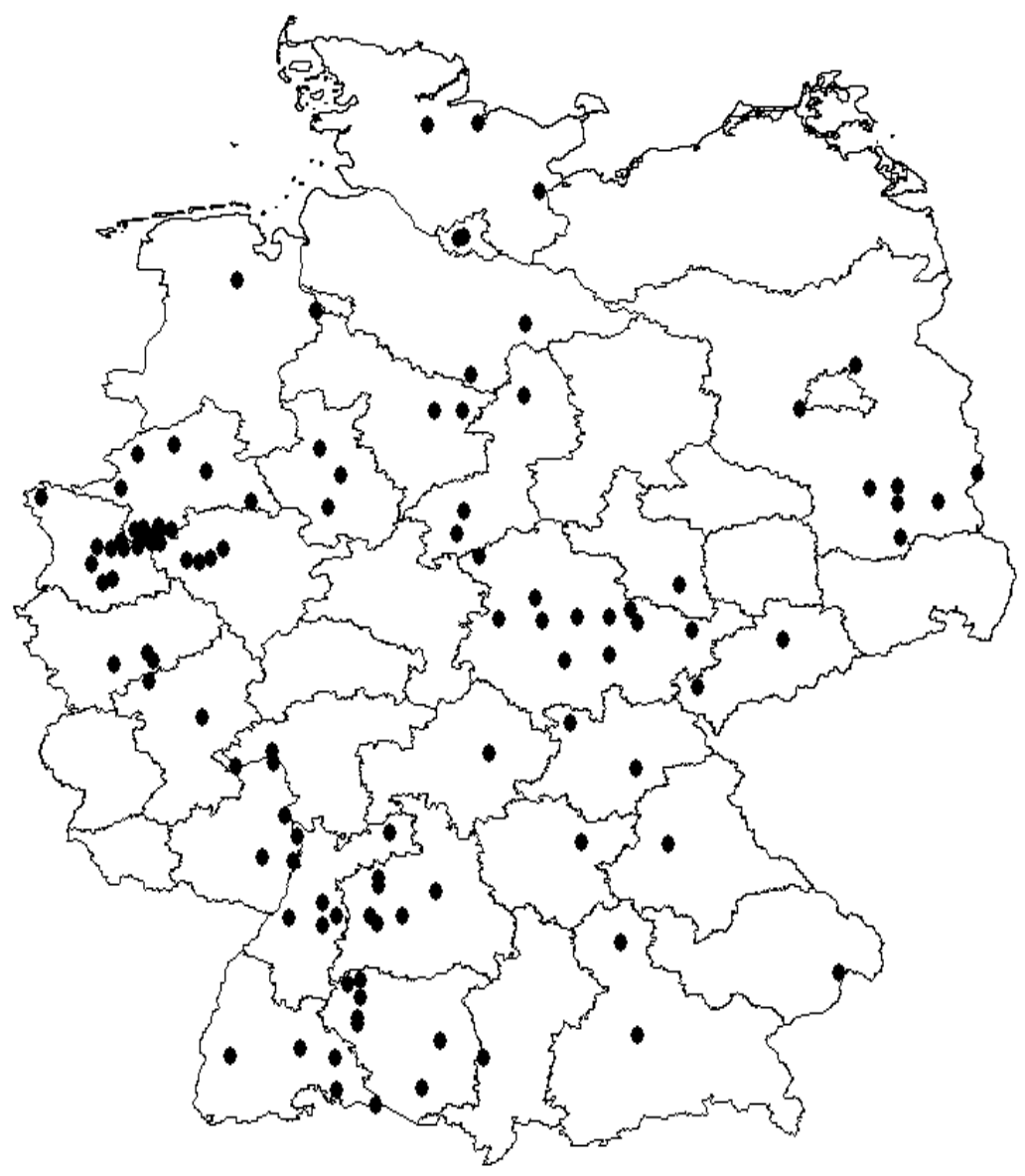

Figure 2: Location of towns and cities in directory sample

How representative is the data of the population in interwar Germany as a whole? To answer this question, we use the standard socio-economic controls for Germany as derived from the nationwide censuses of 1925 and 1933. These give the proportions of various occupations, religious affiliation, and (for 1933) unemployment rates. In addition, we draw on the extensive coding of Weimar voting results by King et al. (2008).

Table 1 compares the national averages with data from towns and cities with surviving directories. By construction, our sample is more urban than the national average. Average population size in the directory sample is 93,000; in 
the country as a whole, it was 12,000 . The employment structure is broadly in line with the aggregate: In the Reich as a whole, $46 \%$ of employees worked in blue collar jobs; in our sample of cities and towns, $52 \%$ did so. Unemployment reached $18.6 \%$ in Germany as a whole in 1933. In our sample, it is higher by 9 percentage points - driven by a more urban environment, with more volatile employment. This difference is much smaller when comparing our sample to the average German city, which had an unemployment rate of 25\% in 1933.

In terms of political preferences, our sample is broadly representative. NS votes in March 33 were 39\% of the total; in the Reich as a whole, the number is $44 \%$. In line with the slight overrepresentation of workers in the directory sample, there is also a higher share of KPD and SPD voters than on the national scale. These differences in election outcomes become minuscule when comparing our sample to the urban averages. The religious composition of our sample suggests an overrepresentation of Catholics. They constituted 32\% of the Reich's population, but their average in our sample is $39.7 \%$. This suggests that we over-sampled Southern areas of Germany, where destruction from bombing raids - carried out principally by aircraft stationed in England - was less. Lower bomb-damage probably facilitated the survival of city archives and library collections. ${ }^{21}$

\footnotetext{
${ }^{21}$ Below, we check if our results hold equally in Catholic and Protestant areas.
} 
Table 1: Data representativeness: Directory sample vs German Reich

\begin{tabular}{lcccccc}
\hline \multirow{2}{*}{ Variable } & \multicolumn{3}{c}{ Means } & \multicolumn{3}{c}{ Standard deviations } \\
& Directory & Urban ${ }^{a}$ & Reich & Directory & Urban $^{a}$ & Reich \\
\cline { 2 - 7 } & & & & & & \\
Socio-economic variables & & & & & & \\
blue collar (1925) & $51.6 \%$ & $48.8 \%$ & $45.9 \%$ & $10.9 \%$ & $10.0 \%$ & $11.5 \%$ \\
white collar (1925) & $43.6 \%$ & $46.1 \%$ & $41.5 \%$ & $9.8 \%$ & $9.0 \%$ & $8.3 \%$ \\
unemployment (1933) & $27.4 \%$ & $25.2 \%$ & $18.6 \%$ & $6.0 \%$ & $7.2 \%$ & $9.3 \%$ \\
pop. size (1933) & 92,916 & 30,924 & 12,973 b & 166,850 & 82,306 & 49,992 b \\
& & & & & & \\
Elections of March 1933 & & & & & & \\
NSDAP & $38.6 \%$ & $38.3 \%$ & $44.1 \%$ & $6.5 \%$ & $8.1 \%$ & $11.4 \%$ \\
Zentrum (conservative) & $15.2 \%$ & $12.9 \%$ & $15.1 \%$ & $12.3 \%$ & $13.7 \%$ & $16.9 \%$ \\
KPD (communists) & $15.8 \%$ & $16.1 \%$ & $11.8 \%$ & $5.6 \%$ & $7.5 \%$ & $7.4 \%$ \\
SPD (social democrats) & $19.2 \%$ & $20.7 \%$ & $17.6 \%$ & $8.2 \%$ & $8.2 \%$ & $8.6 \%$ \\
& & & & & & \\
Religious affiliation & & & & & & \\
Protestant (1925) & $58.9 \%$ & $63.3 \%$ & $63.4 \%$ & $26.5 \%$ & $27.4 \%$ & $32.8 \%$ \\
Jewish (1925) & $1.1 \%$ & $1.5 \%$ & $0.9 \%$ & $0.7 \%$ & $2.0 \%$ & $1.5 \%$ \\
Catholic (1925) & $39.7 \%$ & $29.9 \%$ & $32.3 \%$ & $30.1 \%$ & $29.4 \%$ & $34.1 \%$ \\
\hline \hline
\end{tabular}

a) Excludes eastern territories (east of the Oder-Neisse line) and towns with less than 5,000 inhabitants.

b) Towns with less than 2,000 inhabitants are not listed individually in the official Reichsstatistik, and are therefore excluded from these calculations.

To calculate rates of entry per location, we use the computerized sample of NS members compiled by the universities of Berlin and Minnesota (Schneider-Haase 1991). The universe of membership cards is 11.6 million strong. ${ }^{22}$ The sample contains information on 42,018 membership cards drawn in 1989, and comprising only pre-1933 party entries. We matched the name of the location for which we have directory data against the Ortsgruppe in the Berlin-Minnesota database. This identifies 6,553 members who joined before 1933, or $15.5 \%$ of all

${ }^{22}$ Every member had two cards - one for the central register originally ordered by name, the other initially ordered by geographical area (but later organized alphabetically, too, by the US authorities). 
digitized cards, which closely resembles the population share of our sample: $14.6 \% .^{23}$

Rates of entry in our sample into the Nazi party varied over time. Figure 3 gives an overview. The boxes show the range of entry rates $\left(25^{\text {th }}\right.$ to $75^{\text {th }}$ percentile). Entry rates were stable or declining between 1925 and 1927, before rebounding sharply. The rise in the rate of entry only stopped in 1931; by 1932, average rates of joining the NSDAP had begun to fall. ${ }^{24}$ Throughout, the cross-sectional dispersion is high, with many towns and cities having almost no entry into the Nazi Party, and others showing fairly high rates of entry.

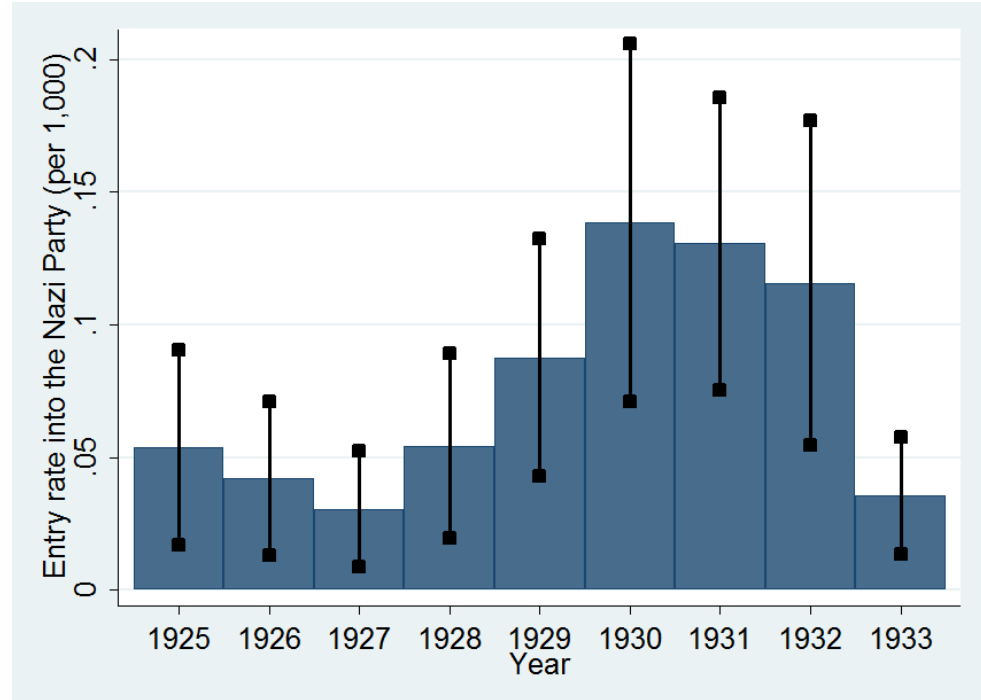

Figure 3: NSDAP party entries 1925-1933, cross-sectional variation (black lines indicate the range based on 0.5 standard deviations)

\footnotetext{
${ }^{23}$ The 103 towns in our sample had altogether 9,111,831 inhabitants in 1925, as compared to a total population of Germany of 62,411,000.

${ }^{24}$ This echoes the fact that the party's electoral successes were beginning to recede by late 1932 . Cf. Turner (1997). After January 1933, entry rates into the party jumped. Because the party feared it would be overwhelmed by the influx of opportunistic members, it imposed a stop on new entrants from April 1933.
} 
One important concern is balancedness. How similar or different are the towns and cities that had above/below average densities of associations? In Table 2, we examine this question. We use voting results for the last pre-World War I election as an indicator of ideological outlook, and also add interwar data on the religious composition of the population, as well as socio-economic characteristics. There are few significant differences. Voter turnout - a standard measure of civic attitudes - was almost identical in cities with above- and below-average turnout in 1912. Areas with low association density had more voters for the SPD, the social democratic party of Germany, which traditionally represented workers' interests. Conservative parties show a mixed pattern: The NLP (National Liberal Party) is underrepresented in areas with many associations, whereas the DKP (German Conservative Party) is overrepresented. Areas with more associations had fewer blue-collar workers in 1925, but the difference is not significant. The share of Jews was relatively similar. There was a higher share of Protestants in towns and cities with few associations. The difference amounts to more than 8 percentage points, but it is not significant. Note that since Protestants were more inclined to join the Nazi Party, this stacks the odds against finding a link between social capital and NS entry. Finally, at the height of the Great Depression, unemployment rates were lower in locations with more civic associations. Thus, if party entry was partly a form of protest against economic conditions, this will actually introduce a downward bias in our main analysis. Overall, there is no evidence that socio-economic or ideological characteristics pre-disposed cities with numerous societies and clubs towards favoring the Nazi Party. ${ }^{25}$

\footnotetext{
${ }^{25}$ Similarly, there is no clear geographical pattern to the location of towns and cities with higher
} than average social capital - cf. Figure A1 in the Appendix. 
Table 2: Balancedness: Controls for high and low association density

\begin{tabular}{llccc}
\hline \hline year & variable & below & above & t-test \\
\hline 1912 & voter turnout 1912 & 0.86 & 0.85 & $(0.62)$ \\
& SPD vote share & 0.35 & 0.30 & $(1.39)$ \\
& National Liberal Party & 0.17 & 0.14 & $(0.68)$ \\
& DKP (German Conservative Party) & 0.03 & 0.06 & $(-1.57)$ \\
1925 & blue collar workers & 0.52 & 0.48 & $(1.92)$ \\
& Jews & 0.01 & 0.01 & $(0.27)$ \\
& Protestants & 0.45 & 0.34 & $(1.68)$ \\
1933 unemployed & 0.25 & 0.19 & $(4.53)$ \\
\hline \hline
\end{tabular}

Note: *below" and "above" refer to the median of association density. The t-test for the corresponding difference is reported in the last column of the table.

\section{Main Results}

In this section, we present our main results. We show that towns and cities with a greater density of civic associations saw more NSDAP member entries. These results hold controlling for a host of socio-economic variables. The link between association density and Nazi party entry is strong during both the party's early, radical phase and after its turn towards legality in 1928. Also, both military associations and singers/animal-breeding clubs have the same predictive power. In combination, we find powerful evidence that a dense fabric of civic associations went hand-in-hand with a more rapid rise of Nazi party membership.

\section{A. Baseline results}

In the following, we examine the link between association density and Nazi Party entry rates by estimating models of the type: 
NSENTRY $_{g}=\alpha+\beta$ ASSOC $_{g}+\gamma \mathbf{X}_{g}+\varepsilon_{g}$

Where NSENTRYg represents different measures of entry into the Nazi Party in location $\mathrm{g}, \alpha$ is a constant, $\mathrm{ASSOC}_{\mathrm{g}}$ are measures of the density of clubs and associations in location $\mathrm{g}$, and $\mathbf{X}_{\mathrm{g}}$ is a vector of controls.

In Table 3, we present the baseline results (reporting beta coefficients). Overall, association density strongly and significantly predicts higher entry rates into the NSDAP. The effect is large - the per capita entry rate increases by approximately 0.4 standard deviations (or by $0.025 / 1000$ ) for every standard deviation increase in association density (1.6/1000). We obtain very similar results for non-military clubs, which consist largely of animal breeders, bowling clubs, singing associations, Carnival clubs, and firefighting associations (col 2). ${ }^{26}$ Military organizations (col 3) are also significant predictors of NS entry. In columns 4-6, we additionally control for socio-economic characteristics. It is well-known, for example, that the Nazi Party scored smaller electoral successes in Catholic areas (Childers 1983). Controlling for factors other than association membership should help to shed light on the extent to which social capital itself facilitated the rise of the Nazi Party. All coefficients remain significant, and of the same order of magnitude. ${ }^{27}$ This suggests that holding class composition and religious affiliations constant, a more prominent role for associations in the social life of a town or city strongly predicts more entry into the Nazi Party. Overall, the results

\footnotetext{
${ }^{26}$ Groups included under the "non-military" rubric include: gymnasts, choirs, animal breeders, music clubs, "Heimat" clubs, citizens associations, and other clubs. Not included are professional associations, such as the local dentists association etc.

${ }^{27}$ This partly reflects the role of the Zentrum, the party representing Catholic interests in Germany. Because Catholics had their "own“ party channeling protest votes, they were less susceptible to the Nazi party's appeal.
} 
show a strong connection between Nazi Party membership and association density - one that is not driven by the religious make-up of the population, by the size of the urban center, or the socio-economic characteristics of a town.

Table 3: Baseline results: Nazi party entry and association density Dependent variable: Nazi Party entry rates, 1925-33

\begin{tabular}{|c|c|c|c|c|c|c|}
\hline & (1) & (2) & (3) & (4) & (5) & (6) \\
\hline ASSOC $_{\text {all }}$ & $\begin{array}{c}0.411^{* * * *} \\
(4.89)\end{array}$ & & & $\begin{array}{c}0.427^{* * *} \\
(4.85)\end{array}$ & & \\
\hline ASSOC $_{\text {non-military }}$ & & $\begin{array}{c}0.233^{* *} \\
(2.62)\end{array}$ & & & $\begin{array}{l}0.290^{* *} \\
(2.64)\end{array}$ & \\
\hline ASSOC $C_{\text {military }}$ & & & $\begin{array}{c}0.391^{* * *} \\
(4.68)\end{array}$ & & & $\begin{array}{c}0.313^{* * *} \\
(3.32)\end{array}$ \\
\hline Share Catholics & & & & $\begin{array}{c}-0.320^{* * *} \\
(-3.85)\end{array}$ & $\begin{array}{c}-0.381^{* * *} \\
(-3.91)\end{array}$ & $\begin{array}{c}-0.354^{* * *} \\
(-3.96)\end{array}$ \\
\hline $\ln ($ рор) & & & & $\begin{array}{l}0.167^{*} \\
(1.91)\end{array}$ & $\begin{array}{c}0.262^{* * *} \\
(2.69)\end{array}$ & $\begin{array}{l}0.140^{*} \\
(1.78)\end{array}$ \\
\hline Share Blue-collar & & & & $\begin{array}{c}-0.231^{* * *} \\
(-3.13)\end{array}$ & $\begin{array}{c}-0.274^{* * *} \\
(-3.16)\end{array}$ & $\begin{array}{c}-0.234^{* * * *} \\
(-3.18)\end{array}$ \\
\hline Observations & 103 & 82 & 97 & 100 & 79 & 94 \\
\hline Adjusted $R^{2}$ & 0.161 & 0.043 & 0.144 & 0.324 & 0.275 & 0.314 \\
\hline
\end{tabular}

To visualize the relationship between association density and Nazi Party entry, we plot the conditional correlation based on col. 4 in Figure 4 . While there are many idiosyncratic factors influencing entry rates, it is clear that towns and cities with high association density, many more citizens joined the Nazi Party. 


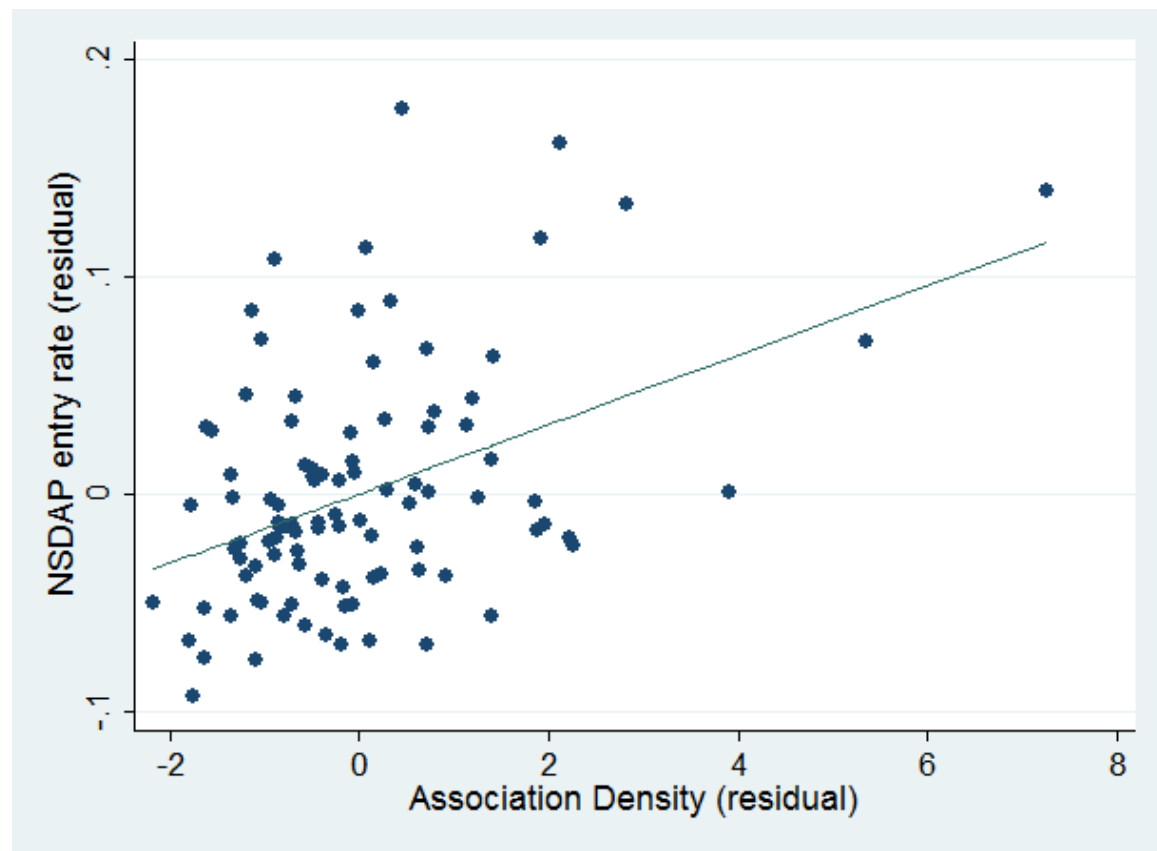

Figure 4: Conditional scatter, NSDAP entry rate and association (based on col 4, Table 3)

Entry rates for the NSDAP were not constant over time, as discussed in section II. Average rates of joining the party fell until 1925, and then increased again - with the rise accelerating after the start of the Great Depression. While social and economic factors played a large role after 1929, we next ask if both early (1924-28) and late (1929-33) Nazi Party entry can be explained by the density of civic networks. In the historical literature, "early" party members are often seen as more committed to the cause - they joined the party shortly after its ban had been lifted, and when its public program emphasized extreme policies including a potentially violent bid for power. After 1928, the party appealed more to middle class voters, favoring a strategy of winning office through peaceful, constitutional means (Childers 1983). Over time, the relative entry rates within locations are stable. As Figure 5 shows, places with a lot of entry in the early years of the party typically remained highly successful at attracting new 
members. While some towns and cities show major upward jumps - like Uelzen or Göttingen - others saw a deterioration in relative performance (Passau, for example).

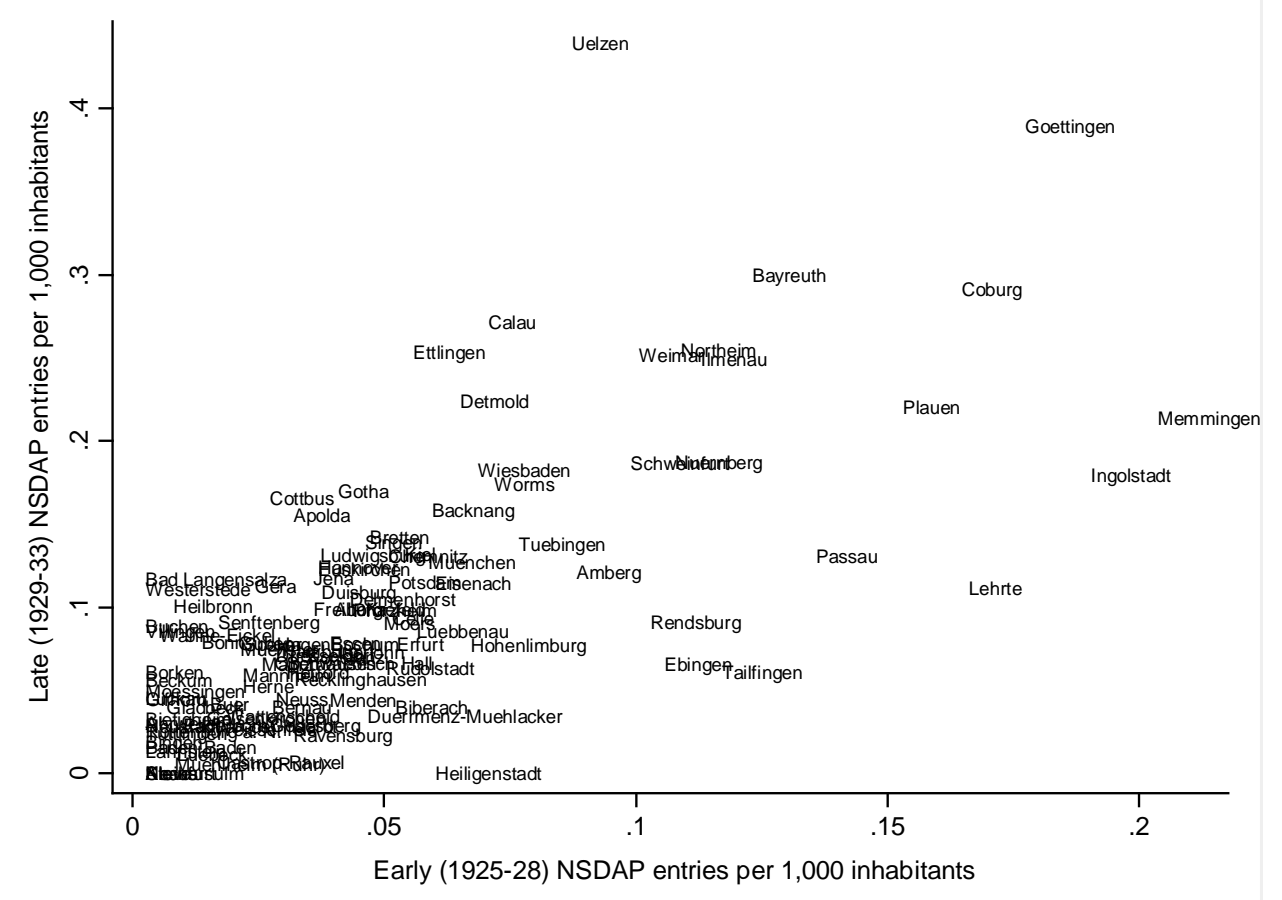

Figure 5: Late (1929-33) Nazi Party entries and early (1924-28) entries, by locality

In Table 4, we use early entry rates as the dependent variable. Results are very similar to the ones obtained before. Coefficients are very similar to those in Table 3, and highly significant. Estimating with late entry also yields largely unchanged results (Appendix C). 
Table 4: Early entries and association density

Dependent variable: Early Nazi Party entry rates, 1925-28

\begin{tabular}{|c|c|c|c|c|c|c|}
\hline & $(1)$ & $(2)$ & (3) & (4) & (5) & (6) \\
\hline ASSOC $_{\text {all }}$ & $\begin{array}{c}0.509^{* * *} \\
(5.50)\end{array}$ & & & $\begin{array}{c}0.551^{* * *} \\
(4.77)\end{array}$ & & \\
\hline ASSOC $_{\text {non-military }}$ & & $\begin{array}{c}0.294^{* * *} \\
(3.13)\end{array}$ & & & $\begin{array}{c}0.327^{* * *} \\
(2.65)\end{array}$ & \\
\hline ASSOC $C_{\text {military }}$ & & & $\begin{array}{c}0.293^{* * *} \\
(2.90)\end{array}$ & & & $\begin{array}{l}0.215^{* *} \\
(2.04)\end{array}$ \\
\hline Share Catholics & & & & $\begin{array}{c}-0.189^{* *} \\
(-2.14)\end{array}$ & $\begin{array}{c}-0.338^{* * *} \\
(-3.35)\end{array}$ & $\begin{array}{c}-0.333^{* * *} \\
(-3.49)\end{array}$ \\
\hline $\ln ($ рор) & & & & $\begin{array}{l}0.158^{*} \\
(1.73)\end{array}$ & $\begin{array}{l}0.189^{*} \\
(1.75)\end{array}$ & $\begin{array}{l}0.058 \\
(0.64)\end{array}$ \\
\hline Share Blue-collar & & & & $\begin{array}{l}-0.101 \\
(-1.19)\end{array}$ & $\begin{array}{l}-0.147 \\
(-1.44)\end{array}$ & $\begin{array}{l}-0.126 \\
(-1.30)\end{array}$ \\
\hline Observations & 103 & 82 & 97 & 100 & 79 & 94 \\
\hline Adjusted $R^{2}$ & 0.252 & 0.075 & 0.077 & 0.304 & 0.204 & 0.177 \\
\hline
\end{tabular}

B. Omitted variable bias

It is possible that our regression results reflect omitted variable bias. For example, it could be argued that NS membership entry was frequent in locations where economic distress was high, and hence the opportunity cost of time was low. This would also translate into more time spent in clubs and associations.

To sidestep this issue, we investigate the deeper history of associations in each city. Association density reflects two factors - the particular incentive to join a club at any one point in time, and the underlying cumulative history of sociability, co-operation, and shared interests. To separate the deeper historical roots of association density from contemporary conditions, we use two instruments from the mid- $19^{\text {th }}$ century. Our first instrument is based on the early history of gymnast associations. Inspired by Friedrich Ludwig Jahn, Germans 
joined gymnast associations ("Turnvereine") in increasing number in the $19^{\text {th }}$ century. While gymnast associations sometimes had a political edge, they were by no means reactionary: German gymnasts were one of the most important groups contributing to the 1848 revolution. There is detailed information on Turnverein membership from the 1860s onwards, after the "Deutsche Turnerschaft" (German Gymnastics Association) was founded. Our second instrument uses participation of town delegates in the 1861 Nuremberg "Sängerfest" (Singers' Festival). Some 283 singing associations participated; the number of singers is given as between 6,000 and 20,000 (Klenke 1998). We normalize both instruments by city population in $1863 .{ }^{28}$

The exclusion restriction is as follows: For gymnast density and singer festival participants to be valid instruments, we have to believe that towns with relatively higher values in the 1860 s only had higher entry rates to the Nazi Party because association density in general was higher there. In other words, there is no direct effect of gymnast membership and singer festival participation on Nazi entry 60-70 years later, and both instruments must also be uncorrelated with other factors that drove NSDAP membership.

One possible threat to the exclusion restriction is that participation in the singer festival or in gymnast associations may potentially reflect aggressive nationalistic

\footnotetext{
${ }^{28}$ Some city boundaries changed over time, especially when surrounding towns and villages were incorporated. This creates large and in some cases, spurious reported population growth in some cases the number of recorded inhabitants grew by more than a factor of 20 between 1863 and 1925. We therefore weigh our regressions by a proxy for the comparability of the 1863 population figure: The ratio of population in 1863 to 1925, relative to average growth over the period. Results are very similar when not weighing, but the first stage is somewhat weaker. For example, for our main specification (column 4 in Table 5), the p-value for the first stage (underidentification test) is 0.04 , and the second-stage beta coefficient is 1.184, with an AndersonRubin p-value of 0.001 .
} 
tendencies of the Nazi type. While both singing and gymnast associations were nationalistic in the early $19^{\text {th }}$ century, they had largely become apolitical after 1850 (Düding 1983): “Germany and other modernizing nations became real to people because many thousands traveled around these nations...meeting their fellow countrymen and singing together" (Applegate 2013), this kind of nationalism was neither militarist nor aggressive. In many cases, the nationalism was fundamentally peaceful, as indicated by the motto of the 1861 Nuremberg singers festival; "in word and song the German banner goes forth/uniting in love both North and South" (Brockmann 2006). The liberal, folk-based nationalism of the $19^{\text {th }}$ century is not to be confused with the political agitation and xenophobia that the Nazis and other right-wing parties represented in Weimar Germany. In sum, while our IV strategy has to be interpreted with caution, we are confident that the exclusion restriction is broadly plausible.

Table 5 gives the results. The first stage is highly significant for most specifications, as reflected by the p-values for the F-test of excluded instruments. For our main specification in column 4, the first stage has a p-value of 0.013. In addition, the overidentification test does not reject instrument exogeneity in any of the specifications. While this result is subject to the usual concern of weak statistical power, it is reassuring with respect to the exclusion restriction of our instruments. In the second stage, we obtain large and statistically significant coefficients on association density. We report p-values based on the AndersonRubin test of statistical significance in square brackets. These are robust to weak instruments (Andrews and Stock 2005).

The IV coefficients are between two and four times larger than their OLS counterparts. Measurement error may be one reason for the difference: In the 
main analysis, we use association density per city, i.e., the number of associations per 1,000 inhabitants in the 1920s. The number of members - which would be a more precise measure - is not available. Both instrumental variables, on the other hand, rely on the number of members/participants. Thus, our instruments may capture both the intensive and extensive margin of association participation. It is plausible that this reduces noise in the estimation, yielding higher coefficients in the second stage. If taken at face value, the IV results imply that a one standard deviation increase in association density is associated with an approximately one standard deviation rise in Nazi party entries (or 0.061 entries per 1,000 inhabitants in our sample, as compared to a mean of 0.076). ${ }^{29}$

\footnotetext{
${ }^{29}$ The Schneider-Haase (1991) sample of about 42,000 membership cards covers $2.1 \%$ of the approximately 2 million NSDAP members in 1932. Therefore, the estimate of 0.061 corresponds to 2.9 entries per 1,000 inhabitants overall - as compared to an average of 32 members per 1,000 inhabitants in 1932 (2 mio members, divided by a population of 62.4 mio).
} 


\section{Table 5: IV results}

Dependent variable: Nazi Party entry rates, 1925-33

\begin{tabular}{|c|c|c|c|c|c|c|}
\hline & $(1)$ & $(2)$ & (3) & $(4)$ & (5) & (6) \\
\hline \multicolumn{7}{|c|}{ Second Stage } \\
\hline ASSOC $_{\text {all }}$ & $\begin{array}{l}1.223 * * * \\
{[0.0007]}\end{array}$ & & & $\begin{array}{l}0.872 * * * \\
{[0.0040]}\end{array}$ & & \\
\hline ASSOC $C_{\text {non-military }}$ & & $\begin{array}{l}1.216 * * * \\
{[0.0035]}\end{array}$ & & & $\begin{array}{l}0.780 * * * \\
{[0.0046]}\end{array}$ & \\
\hline ASSOC $_{\text {military }}$ & & & $\begin{array}{l}1.232 * * * \\
{[0.0012]}\end{array}$ & & & $\begin{array}{l}1.115 * * * \\
{[0.0048]}\end{array}$ \\
\hline Controls & No & No & No & Yes & Yes & Yes \\
\hline \multicolumn{7}{|c|}{ First stage for association density } \\
\hline $\begin{array}{l}\text { p-value for } \\
\text { instruments }\end{array}$ & 0.009 & 0.060 & 0.023 & 0.013 & 0.068 & 0.165 \\
\hline $\begin{array}{l}\text { Overidentification } \\
\text { test (p-value) }\end{array}$ & 0.816 & 0.846 & 0.462 & 0.433 & 0.345 & 0.345 \\
\hline$N$ & 103 & 82 & 97 & 100 & 79 & 94 \\
\hline
\end{tabular}

Standardized beta coefficients; ${ }^{*} p<0.10,{ }^{* *} p<0.05,{ }^{* * *} p<0.01$. ASSOC $_{\text {all }}$ is the number of associations per 1,000 inhabitants in each city; $A S S O C_{\text {non-military }}$ and $A S S O C_{\text {military }}$ give this number for non-military and military associations, respectively. Second stage results report the p-values [in square brackets] for the Anderson-Rubin test of statistical significance (heteroskedasticity-robust). This test is robust to weak instruments (see Andrews and Stock, 2005 for a detailed review). Controls include \%Catholic, $\ln ($ population), and \%of blue collar workers, all measured at the city level in 1925. Instruments in the first stage are the density of gymnast association members in the 1860s (per 1,000 inhabitants in 1863), and participants from each city in the 1861 Sängerfest (singer festival) in Nuremberg (again normalized by city population in 1863). All regressions are weighted by a proxy for the comparability of 1863 population data, due to territorial changes (see footnote 28 for detail).

We cannot fully exclude the possibility that our instruments affect Nazi party entry via channels other than association density. We allow for deviations from perfect instrument exogeneity, using the method in Conley, Hansen and Rossi (2012). In this way, we examine the consequences of a possible direct effect on party entry. Appendix D summarizes this analysis. It shows that, for our IV result to become insignificant, the direct effect of the instruments would have to be at least one-half of their overall reduced form effect on party entry. In other words, Sängerfest participation in 1861 and the density of gymnasts in the 1860s 
would have to be at least half as potent a pathway to NS membership as participation in clubs and associations in the 1920s - which seems improbable. The Conley et al. results strongly suggests that the IV estimates are robust even to substantial deviations from strict exogeneity.

One alternative to deal with omitted variable bias is to perform a bounding exercise in the spirit of Altonji, Elder, and Taber (2005). They use selection on observables in order to assess the potential bias from unobservables. We compute the ratio constructed by Altonji, Elder, and Taber (2005) which compares how much the coefficient on the variables of interest (total association density, density of military and non-military associations) declines as control variables are added.

We run two sets of regressions. First, we estimate (1) without controls and denote the corresponding coefficient $\hat{\beta}^{A}$. Next, we estimate (1) with our standard set of controls (\%Catholic, $\ln ($ population), and \%blue collar, and denote the coefficient on $\mathrm{ASSOC}_{\mathrm{g}}$ by $\hat{\beta}^{B}$. Then, the Altonji et al. ratio is given by $\hat{\beta}^{B} /\left(\hat{\beta}^{A}-\hat{\beta}^{B}\right)$. Intuitively, the larger $\hat{\beta}^{B}$ the stronger is the effect that is left after controlling for observables - and the more would unoberservables have to explain in order to reduce the coefficient to zero. As for the denominator in the ratio, the smaller is the difference between $\hat{\beta}^{A}$ and $\hat{\beta}^{B}$, the less is the estimated coefficient influenced by observables, and the stronger would selection on unobservables have to be relative to selection on observables in order to completely explain away the effect. Importantly, this approach assumes that the variation in Nazi party entries related to the observables has the same relationship with local association density as the part of the variation reflecting unobservables. 
Given these changes, we estimate how much stronger the effect of omitted variables would have to be, relative to observables, to attribute the entire OLS estimates to selection effects. Table 6 presents the results. In three cases, the implied ratios are negative. This occurs when the observable controls are on average negatively correlated with party entry, yielding stronger coefficient estimates than in the basic regression without controls. In these cases, the AltonjiElder-Taber test suggests that our OLS estimates are likely to be downwardbiased (provided that the unobservables are positively correlated with the observables). When there is positive correlation between party entry and observables, the ratios range from 3.3 to 8.5 . This implies that selection on unobservables would have to be at least three times stronger than selection on observables for our main result to be overturned. For the main result using all associations, the coefficient is the least affected by adding controls, suggesting that unobservables would have to be 8.5 times stronger in their effect than observables in order to fully account for the observed effect.

\section{Table 6: Selection on Unobservables}

\begin{tabular}{llllc}
\hline \hline $\begin{array}{l}\text { Controls } \\
\text { restricted set }\end{array}$ & $\begin{array}{l}\text { Controls in } \\
\text { full set }\end{array}$ & Association density includes \\
All & $\begin{array}{c}\text { Non- } \\
\text { military }\end{array}$ & Military \\
\hline none & \%Catholic, $\ln ($ pop), \%blue collar & {$[<0]$} & {$[<0]$} & 3.3 \\
\hline \multirow{3}{*}{ none } & $\begin{array}{l}\text { above + unemp. 1933, share of Jews } \\
\text { in 1925, controls from the 1912 }\end{array}$ & 8.5 & {$[<0]$} & 4.2 \\
& $\begin{array}{l}\text { federal election: turnout, SPD, NLP, } \\
\text { DKP votes }\end{array}$ & & & \\
\hline \hline
\end{tabular}

The table reports the relative strength of selection on unobservables that is required to completely explain the effect of each association density measure on Nazi party entry, using the methodology from Altonji, Elder, and Taber (2005). The entry $[<0]$ indicates that the respective Altonji et al ratio is negative; in these cases, observables are on average negatively correlated with the outcome variable, suggesting a downward bias for our OLS estimates due to unobservables (if these have similar correlation patterns as the included observables). 


\section{Disaggregating social capital}

Social capital comes in different types. For example, Putnam distinguishes between "bonding" and "bridging" social capital. The former cements preexisting cleavages in a society, by making exclusive groups even more exclusive; the latter brings people from different walks of life together, facilitating interactions amongst equals. According to Putnam, bonding social capital may have adverse effects; bridging social capital should always have benign consequences.

To analyze this further, we classify the entire list of organizations in each town according to their type. Appendix B provides the full classification scheme. To fix ideas, we give two simple examples. In interwar Germany, a typical bridging club was a local choir - only enthusiasm for singing (and a good voice) were needed, and there were no monetary, social, or gender barriers to entry. A good example of a bonding association are the Herrenclubs - broadly similar to London clubs, they were, as their name suggests, designed as socially exclusive associations for members of the old, land-owning elite and the new wealthy upper class.

Table 7 gives the results of regressing Nazi Party entry rates on the density of bridging and bonding associations. ${ }^{30}$ Bonding associations are strongly associated with NS party entry. Without controls, the effect appears weaker for bridging social capital. Note that the two coefficients are not significantly

\footnotetext{
${ }^{30}$ Note that the correlation coefficient of the two densities is not high; it is 0.23 in our sample.
} 
different from each other. Once all controls are included, we find positive, significant, and quantitatively meaningful coefficients on bonding and bridging capital. This suggests that both associations contributing to bonding and bridging social capital were important pathways for the spread of the Nazi Party.

Table 7: Bridging and bonding capital

Dependent variable: Nazi Party entry rates, 1925-33

\begin{tabular}{|c|c|c|c|c|}
\hline & (1) & (2) & (3) & (4) \\
\hline ASSOC $_{\text {bonding }}$ & $\begin{array}{c}0.450^{* * *} \\
(3.15)\end{array}$ & & $\begin{array}{l}0.325^{* *} \\
(2.02)\end{array}$ & \\
\hline ASSOC ${ }_{\text {bridging }}$ & & $\begin{array}{l}0.144 \\
(1.60)\end{array}$ & & $\begin{array}{l}0.217^{*} \\
(1.85)\end{array}$ \\
\hline Share Catholics & & & $\begin{array}{c}-0.337^{* * *} \\
(-3.89)\end{array}$ & $\begin{array}{c}-0.405^{* *} \\
(-4.55)\end{array}$ \\
\hline $\ln ($ рор) & & & $\begin{array}{l}0.120 \\
(1.55)\end{array}$ & $\begin{array}{l}0.196^{*} \\
(1.90)\end{array}$ \\
\hline Share Blue-collar & & & $\begin{array}{c}-0.180^{* *} \\
(-2.48)\end{array}$ & $\begin{array}{c}-0.279^{* *} \\
(-3.69) \\
\end{array}$ \\
\hline Observations & 97 & 97 & 94 & 94 \\
\hline Adjusted $R^{2}$ & 0.194 & 0.011 & 0.313 & 0.257 \\
\hline
\end{tabular}

\section{Robustness}

How robust are our findings? We examine the strength of the main effect in varying subsamples, the use of alternative estimators, and of the logarithm of the dependent variable.

In Table 8, we define various subsamples. Do the main results hold if we look at predominantly Protestant areas? Do towns and cities with more workers provide less effective recruiting grounds via associations for the Nazi Party? Is the share of Jews in the population an important modifying variable? The results suggest that, while the size of effects varies, the basic relationship between civic 
associations and membership entry remains the same. Where Catholics dominated, more clubs and societies led to proportionately faster entry than in Protestant areas (col 1 and 2), but the effects are highly significant in both cases. Localities with a predominance of workers saw smaller increases in NS entry as a function of association density. Catholic areas were typically more resistant to the lure of the Nazi Party. That is why it is surprising that where Catholics were in a majority, the NSDAP grew particularly quickly the denser the network of associations. Workers were not an ideal recruiting ground for the Party, which can explain why association density in areas with many workers mattered less in driving up overall entry rates. There is also no evidence that the presence of Jews modified the basic relationship between the density of civic associations and the rise of Nazi membership. Finally, we

Table 8: Subsamples

Dependent variable: Nazi Party entry rates, 1925-33

\begin{tabular}{|c|c|c|c|c|c|c|c|c|}
\hline & (1) & (2) & (3) & (4) & (5) & (6) & (7) & (8) \\
\hline & \multicolumn{2}{|c|}{ Catholic share } & \multicolumn{2}{|c|}{ Worker share } & \multicolumn{2}{|c|}{$\begin{array}{l}\text { Jewish share (rel. } \\
\text { to median) }\end{array}$} & \multicolumn{2}{|c|}{$\begin{array}{l}\text { City size (rel. to } \\
\text { median) }\end{array}$} \\
\hline & $<50 \%$ & $\geq 50 \%$ & $<50 \%$ & $\geq 50 \%$ & below & above & below & above \\
\hline \multirow[t]{2}{*}{$\overline{A S S O C_{\text {all }}}$} & $0.319^{* *}$ & $0.670^{* * *}$ & $0.460^{* * *}$ & $0.320^{*}$ & $0.452^{* * *}$ & $0.437^{* * *}$ & $0.0178^{* * * *}$ & $0.0117^{*}$ \\
\hline & $(2.16)$ & (3.95) & $(5.21)$ & (1.76) & (2.85) & (5.06) & (5.02) & (1.86) \\
\hline \multirow{2}{*}{$\begin{array}{l}\text { Share } \\
\text { Catholics }\end{array}$} & -0.09 & 0.049 & $-0.41^{* * * *}$ & -0.145 & $-0.314^{* *}$ & $-0.34^{* * *}$ & $-0.071^{* * *}$ & $-0.04^{*}$ \\
\hline & $(-0.86)$ & -0.37 & $(-3.75)$ & $(-0.94)$ & $(-2.44)$ & $(-3.00)$ & $(-2.85)$ & $(-1.85)$ \\
\hline \multirow[t]{2}{*}{$\ln ($ рор) } & 0.053 & $0.309^{* *}$ & 0.08 & 0.178 & 0.195 & 0.101 & 0.0157 & 0.00251 \\
\hline & $(0.41)$ & (2.36) & $(0.7)$ & (1.19) & (1.5) & $(0.81)$ & (1.08) & $(0.3)$ \\
\hline \multirow{2}{*}{$\begin{array}{l}\text { Share } \\
\text { col. }\end{array}$} & $-0.39^{* * *}$ & -0.002 & -0.044 & $-0.310^{* *}$ & $-0.273^{* *}$ & -0.102 & -0.0857 & $-0.170^{* *}$ \\
\hline & $(-3.18)$ & $(-0.02)$ & $(-0.38)$ & $(-2.04)$ & $(-2.55)$ & $(-0.92)$ & $(-1.33)$ & $(-3.26)$ \\
\hline Observations & 58 & 42 & 61 & 39 & 49 & 51 & 50 & 50 \\
\hline Adjusted $R^{2}$ & 0.272 & 0.325 & 0.336 & 0.124 & 0.313 & 0.289 & 0.4 & 0.324 \\
\hline
\end{tabular}

Standardized beta coefficients; $t$ statistics in parentheses $* p<0.10,{ }^{* *} p<0.05$, $* * * p<0.01$. ASSOC $_{\text {all }}$ is the number of associations per 1,000 inhabitants in each city. 
So far, we have only controlled for the share of population that is Catholic, for the share of blue-collar workers, and the size of each city. In addition, we can examine the effect of controlling for a much wider range of additional variables, including the indicators used in Table 2, where we examined balancedness. Table 9 presents the results if we add measures of civic engagement in 1912 (voter turnout in the national election of that year), the vote shares of the main parties, as well as the percentage of Jews in each town and the unemployment rate in 1933. There are few significant findings that are consistent across specifications. Neither votes for the SPD nor the share of Jews is significantly associated with entry rates into the Nazi Party. The depth of economic downturn in 1933 - which may reflect underlying economic vulnerabilities in the 1920s already - is also not significantly associated with party entry. The one exception is the vote share of the DKP - the German Conservative Party. The effect is unambiguously negative, underlining the important ideological (and class) differences between German conservatism in general and National Socialism. 
Table 9: Additional controls

Dependent variable: Nazi Party entry rates, 1925-33

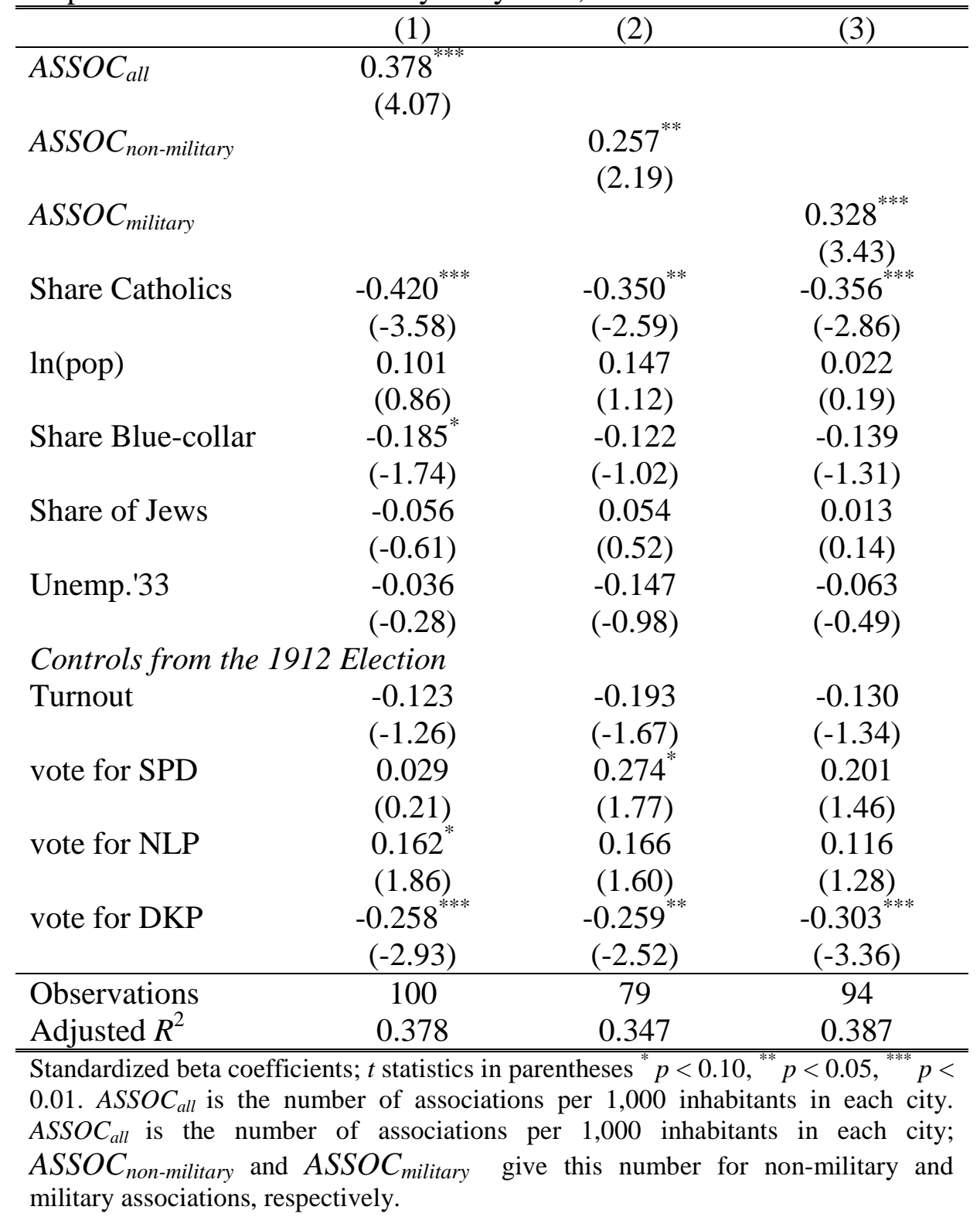

There is no particular reason to use either entry rates or the log of entry rates as a dependent variable. In Appendix C, we show that results are largely unchanged if we use a log specification. 
To examine the potential effect of outliers, we use a robust estimator that first drops all observations with a Cook's D statistic greater than unity (Table 10); in a second round, the influence of the remaining observation is reduced using Huber weighting, i.e., in line with the size of the OLS residual. Down-weighting observations with high leverage does not affect our results: The size and significance of coefficients is close to the baseline in Table 3. The same conclusion arises when we use median regressions as an alternative way to reduce the influence of extreme values (Appendix C).

Table 10: Robust regression results

Dependent variable: Nazi Party entry rates, 1925-33

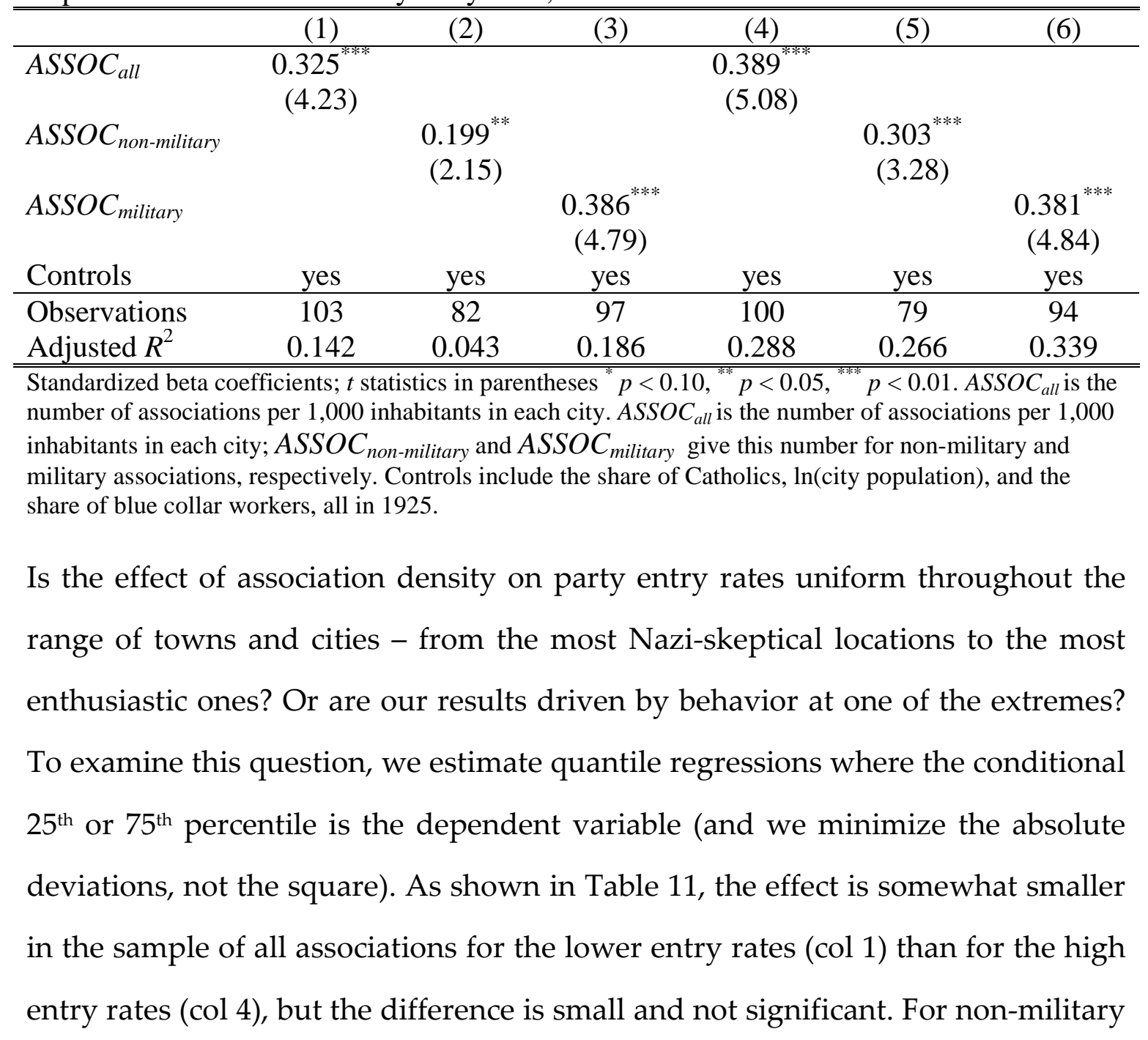


groups, the size of the coefficients is very similar, and for military associations, entry rates are somewhat more strongly influenced at the top end. ${ }^{31}$

\section{Table 11: Quantile regressions}

Dependent variable: Nazi Party entry rates, 1925-33

(1)

${ }{ }^{2 S S O C}$ all $\quad 0.325^{* * *}$

$A_{S S O C}$ non-military

(2) $25^{\text {th }}$ percentile

(3)

(4)

(5)

(6)
$A S S O C_{\text {military }}$

0.422

$$
0.256^{* * *}
$$

$0.222^{* * *}$

Controls

Observations

yes

yes

yes

$79 \quad 94$

Standardized beta coefficients; $t$ statistics in parenthese ${ }^{*} p<0.10,{ }^{* *} p<0.05,{ }^{* * *} p<0.01$. ASSOC $_{\text {all }}$ is the number of associations per 1,000 inhabitants in each city. $A S S O C_{\text {all }}$ is the number of associations per 1,000

inhabitants in each city; $A S S O C_{\text {non-military }}$ and $A S S O C_{\text {military }}$ give this number for non-military and military associations, respectively. Controls include the share of Catholics, $\ln ($ city population), and the share of blue collar workers, all in 1925.

\section{Conclusion}

When is social capital beneficial? Theoretically, closer ties between citizens can cut both ways - facilitating co-operation for benign and detrimental ends. While a rich literature has documented desirable outcomes associated with denser networks of civic associations and clubs, the analysis of negative outcomes has mostly focused on crime and related activities (Field 2003). In this study, we argue that well-documented advantages also have to be balanced against substantial risks to democracy itself: In interwar Germany at least, the vigor of German civic society facilitated the spread of the Nazi Party, thus contributing to

\footnotetext{
${ }^{31}$ In Appendix C, we plot the full range of coefficients for all quantiles from the 10th to the 90th, for the main specification (for all associations, with controls).
} 
the eventual collapse of democracy and the rise of one of the most destructive regimes in history. This suggests that the dark side of social capital - in one famous and arguably pivotal case - went far beyond the criminal activities and the entrenchment of established politicians (Acemoglu, Reed, and Robinson 2013). This finding is also in stark contrast to an earlier literature that had blamed Germany's path to dictatorship on a "civic non-age" of low social capital, harking back to the $19^{\text {th }}$ century (Stern 1972). ${ }^{32}$

Our conclusion emerges clearly from new cross-sectional evidence collected from municipal archives and city libraries for the purpose of our study. In towns and cities with more grass-root clubs and associations, the Nazi Party grew markedly faster. This is true both for the party's early years and for its final ascendancy to power, after the start of the Great Depression. There is also good reason to believe that the link is causal: The share of variation in civic society indicators explained by deeper historical roots of association-based sociability strongly predicts NS entry rates.

Tocqueville (1835), who pioneered the argument that social capital was crucial for the vigor of democracy, was well-aware of the ambiguities involved. In particular, he observed that civic associations could also undermined the vigor of democracy, depending on the maturity of institutions and the cultural context:

The most natural privilege of man... is that of combining his exertions with those of his fellow creatures and of acting in common with them. The right of association therefore appears to me almost as inalienable in its

\footnotetext{
32 Stern argued that Germans lacked "the kind of voluntary, civic activity that attracted their English and American counterparts... Civic initiative takes practice, and German society never fostered it. Most Germans looked to the state for guidance and initiative." (Stern 1972).
} 
nature as the right of personal liberty. ... Nevertheless, if the liberty of association is only a source of advantage and prosperity to some nations, it may be perverted or carried to excess by others, and from an element of life may be changed into a cause of destruction. [italics added]

In line with Tocqueville's reasoning, we find that social capital can indeed have a "dark side", and that it can imperil the survival of democracy when it facilitates the growth of an extremist movement. It therefore becomes crucial to ask under what set of specific conditions the widely documented benefits outweigh the rare - but catastrophic - costs that a vibrant civil society can also entail. 


\section{Bibliographical references}

Abel, Theodore Fred. 1938. Why Hitler Came into Power: An Answer Based on the Original Life Stories of Six Hundred of His Followers. Prentice-Hall, inc.

Acemoglu, Daron, Tristan Reed, and James A. Robinson. 2013. "Chiefs: Elite Control of Civil Society and Economic Development in Sierra Leone”. Working Paper 18691. National Bureau of Economic Research. http://www.nber.org/papers/w18691.

Altonji, Joseph G., Todd E. Elder, and Christopher R. Taber. 2005. "Selection on Observed and Unobserved Variables: Assessing the Effectiveness of Catholic Schools.” Journal of Political Economy 113 (1): 151-184.

Andrews, Donald W. K., and James H. Stock. 2005. "Inference with Weak Instruments". Working Paper 313. National Bureau of Economic Research. http://www.nber.org/papers/t0313.

Anheier, Helmut K. 2003. "Movement Development and Organizational Networks: The Role of 'Single Members' in the German Nazi Party, 1925-1930.” In Social Movements and Networks: Relational Approaches to Collective Action, edited by Mario Diani and Doug McAdam, 49-78. Oxford, UK: Oxford University Press. http://www.oup.co.uk/.

Bai, Jushan, and Serena Ng. 2010. "Instrumental Variable Estimation in a Data Rich Environment.” Econometric Theory 26 (6): 1577.

Berman, Sheri. 1997. "Civil Society and the Collapse of the Weimar Republic." World Politics 49 (3): 401-429. doi:10.1353/wp.1997.0008.

Brockmann, Stephen. 2006. Nuremberg: The Imaginary Capitol. Camden House.

Brustein, Professor William. 1998. The Logic of Evil: The Social Origins of the Nazi Party, 1925-1933. Yale University Press.

Chambers, Simone, and Jeffrey Kopstein. 2001. "Bad Civil Society.” Political Theory 29 (6): 837-865.

Childers, Thomas. 1983. The Nazi Voter: The Social Foundations of Fascism in Germany, 1919-1933. The University of North Carolina Press.

Conley, Timothy G, Christian B Hansen, and Peter E Rossi. 2012. "Plausibly Exogenous." Review of Economics and Statistics 94 (1): 260-272.

Costa, Dora L., and Matthew E. Kahn. 2007. "Surviving Andersonville: The Benefits of Social Networks in POW Camps.” American Economic Review 97 (4): 14671487.

- 2008. "Heroes and Cowards: The Social Face of War". NBER Books. National Bureau of Economic Research, Inc. http://ideas.repec.org/b/nbr/nberbk/cost081.html.

Creveld, Martin Van. 1982. Fighting Power: German and US Army Performance, 19391945. Greenwood Press.

Dasgupta, Partha, and Ismail Serageldin. 2000. Social Capital: a Multifaceted Perspective. World Bank Publications.

Düding, Dieter. 1984. Organisierter Gesellschaftlicher Nationalismus in Deutschland (1808-1847): Bedeutung Und Funktion Der Turner- Und Sangervereine Fur Die Deutsche ... Neunzehnten Jahrhunderts). R. Oldenbourg. 
Dunn, John. 1979. Western Political Theory in the Face of the Future. Cambridge University Press.

Durlauf, Steven N., and Marcel Fafchamps. 2004. “Social Capital”. NBER Working Paper 10485. National Bureau of Economic Research, Inc. http://ideas.repec.org/p/nbr/nberwo/10485.html.

Eley, Geoff. 1980. Reshaping the German Right: Radical Nationalism and Political Change after Bismarck: with a New Introduction. University of Michigan Press.

Falter, Jurgen W. 1991. Hitlers Wähler. Beck.

Field, John. 2003. Social Capital. Routledge.

Grootaert, Christian, and Thierry van Bastelaer. 2002. Understanding and Measuring Social Capital: A Multidisciplinary Tool for Practitioners. World Bank Publications.

Guiso, Luigi, Paola Sapienza, and Luigi Zingales. 2008. "Long Term Persistence”. NBER Working Paper 14278. National Bureau of Economic Research, Inc. http://ideas.repec.org/p/nbr/nberwo/14278.html.

Gutmann, Amy. 1998. Freedom of Association. Princeton University Press.

Hamilton, Richard F. 1982. Who Voted for Hitler? Princeton University Press.

Haupt, Herman. 1925. Handbuch für den deutschen burschenschafter. M., Verlag der Burschenschaftlichen blätter.

Heiden, Konrad. 1935. A History of National Socialism. A.A. Knopf.

Kater, Michael H. 1983. The Nazi Party: A Social Profile of Members and Leaders, 1919-1945. Harvard University Press.

King, Gary, Ori Rosen, Martin Tanner, and Alexander F. Wagner. 2008. “Ordinary Economic Voting Behavior in the Extraordinary Election of Adolf Hitler." The Journal of Economic History 68 (04): 951-996. doi:10.1017/S0022050708000788.

Knack, Stephen, and Philip Keefer. 1997. "Does Social Capital Have an Economic Payoff? A Cross-Country Investigation.” The Quarterly Journal of Economics 112 (4): 1251-88.

Koshar, Rudy. 1986. Social Life, Local Politics, and Nazism: Marburg, 1880-1935. University of North Carolina Press.

Linz, Juan José. 1976. "Some Notes Toward a Comparative Study of Fascism in Sociological Historical Perspective.” In Fascism: A Readers' Guide: Analysis,Interpretations and Bibliography, ed.Walter Laqueur, 3-121. Berkeley: University of California Press.

Madden, Paul, and Detlef Mühlberger. 2007. The Nazi Party: The Anatomy of a People's Party, 1919-1933. 1st ed. Peter Lang Pub Inc.

Mommsen, Hans. 1978. “4. National Socialism : Continuity and Change.” In Fascism : A Readers' Guide: Analysis,Interpretations and Bibliography, 179-210. University of California Press.

Mühlberger, Detlef. 2003. The Social Bases of Nazism, 1919-1933. Cambridge University Press.

Nipperdey, Thomas. 1976. Gesellschaft, Kultur, Theorie: Gesammelte Aufsätze Zur Neueren Geschichte. Kritische Studien Zur Geschichtswissenschaft Bd. 18. Göttingen: Vandenhoeck und Ruprecht. 
Obermann, Karl. 1963. "Die Politische Rolle Der Turnvereine in Der Demokratischen Bewegung Am Vorabend Der Revolution von 1848.” Theorie Und Praxis Der Körperkultur 9: 795-805.

Putnam, Robert. 1995. “Bowling Alone: America’s Declining Social Capital.” Journal of Democracy 6 (1): 65-78. doi:10.1353/jod.1995.0002.

- 2000. Bowling Alone: The Collapse and Revival of American Community. New York: Simon \&amp; Schuster.

Putnam, Robert D., and Kristin A. Goss. 2002. Democracies in Flux. Introduction. Oxford University Press. http://www.oxfordscholarship.com/view/10.1093/0195150899.001.0001/acprof9780195150896.

Reichardt, Sven. 2004. "Selbstorganisation Und Zivilgesellschaft : Soziale Assoziationen Und Politische Mobilisierung in Der Deutschen Und Italienischen Zwischenkriegszeit.” In Zivilgesellschaft Als Geschichte: Studien Zum 19. Und 20. Jahrhunder. Wiesbaden : VS Verl. für Sozialwissenschaften.

Schneider-Haase, D.T. 1991. "Beschreibung Der Stuchprobenziehung Zu Den, Mitgliedernder NSDAP Vom 27. Maerz - 7.September 1989 Im Berlin Document Center.” Historical Social Research.

Shirer, William L. 1960. The Rise and Fall of the Third Reich: A History of Nazi Germany. Simon \& Schuster.

Stachura, Peter D. 1981. The German Youth Movement 1900 - 1945: 1900 - 1945 ; an Interpretative and Documentary History. St. Martin's Press.

Stephan, Werner. 1931. "Zur Soziologie Der Nationalsozialistischen Deutschen Arbeiterpartei” Zeitschrift für Politik,XX (March): 794-95.

Stern, Fritz. 1972. The Failure of Illiberalism. George Allen \& Unwin.

Susan Saegert, and Gary Winkel. 2004. "Crime, Social Capital, and Community Participation.” American Journal of Community Psychology 34 (3-4): 219-233. doi:10.1007/s10464-004-7416-2.

Tocqueville, Alexis de. 1835. De La Démocratie En Amérique.

Turner, Henry Ashby. 1997. Hitler's Thirty Days To Power: Jan-33. Basic Books.

Wentzcke, Paul. 1965. Geschichte der Deutschen Burschenschaft. Carl Winter.

Winkelried, Diego, and Richard J Smith. 2011. "Principal Components Instrumental Variable Estimation”. Faculty of Economics, University of Cambridge.

Winkler, Heinrich August. 1987. Der Weg in Die Katastrophe: Arbeiter Und Arbeiterbewegung in Der Weimarer Republik 1930 Bis 1933. Geschichte Der Arbeiter Und Der Arbeiterbewegung in Deutschland Seit Dem Ende Des 18. Jahrhunderts Bd. 11. Berlin: J.H.W. Dietz Nachf.

Wolf, Heinrich. 1972. Der Jungdeutsche Orden in seinen mittleren Jahren.

Zeiss-Horbach, Auguste. 2008. Der Verein zur Abwehr des Antisemitismus: zum Verhältnis von Protestantismus und Judentum im Kaiserreich und in der Weimarer Republik. Evangelische Verlagsanstalt. 


\section{ONLINE APPENDIX}

\section{BOWLING FOR FASCISM: SOCIAL CAPITAL AND THE RISE OF THE NAZI \\ Party in Weimar Germany, 1919-33}
Shanker Satyanath
Nico Voigtländer
Hans-Joachim Voth
NYU
UCLA and NBER
UPF and CREI

\section{Appendix A: Additional results}

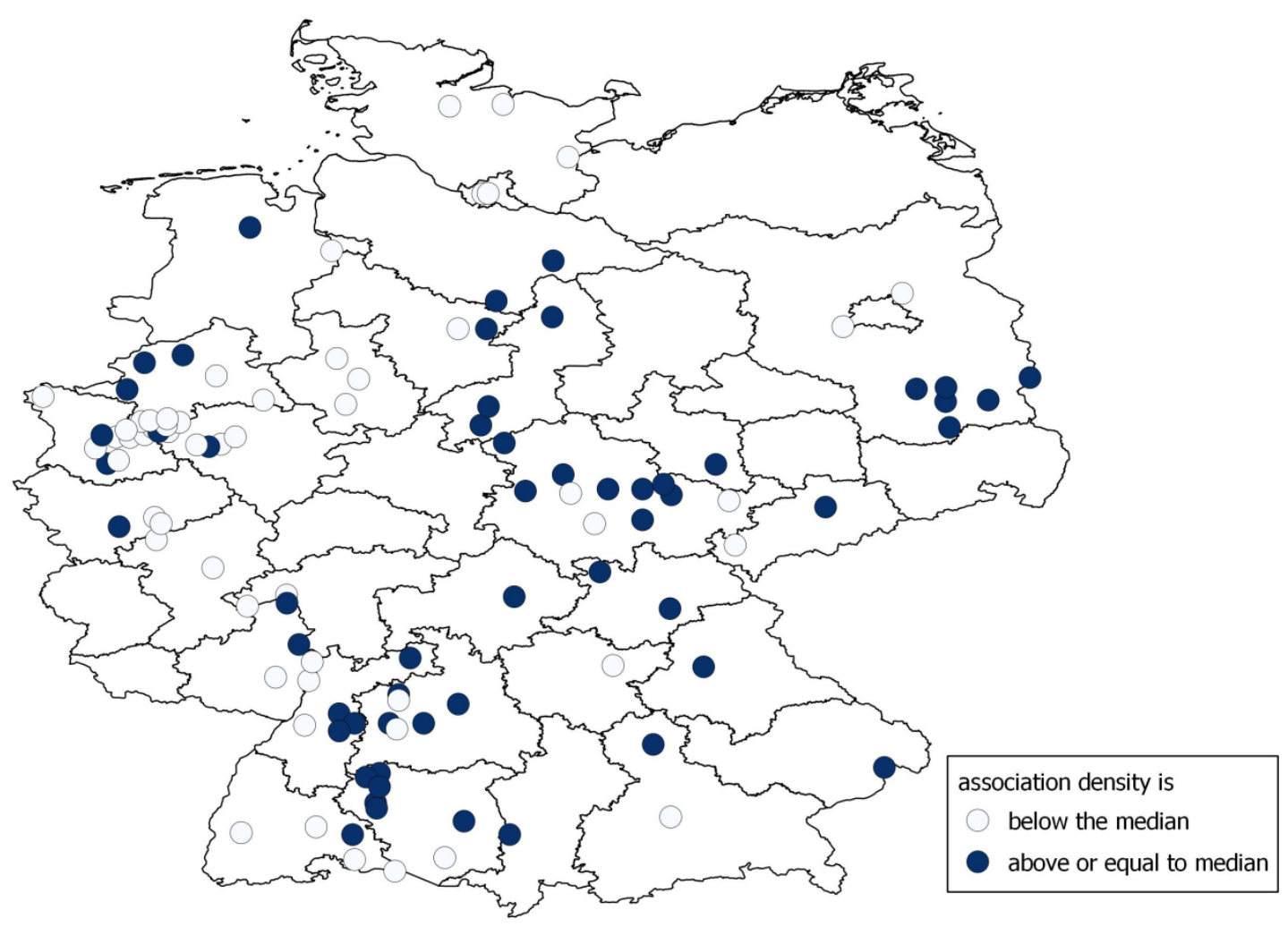

Figure A1: Geographical distribution of towns and cities with above/below average social capital 


\title{
Appendix B: Classification scheme - "bridging" vs “bonding" social capital
}

\author{
Bridging social capital \\ Bonding social capital \\ - Gymnastic clubs \\ - Athletic associations \\ - Verein Deutscher Studenten \\ - Rifle clubs \\ - Animal breeding \\ - Singing associations \\ - Hunters \\ - Corps \\ - Burschenschaften \\ - Music clubs \\ - Chess players \\ - "odd fellows" etc. \\ - Alpine societies \\ - Youth clubs
}

\section{Appendix C: Further robustness checks}

In this appendix, we examine the effect of using logs of the dependent variable, and examine the robustness of our findings by using median regressions. Table C. 1 shows that we obtain results that are very similar to the baseline in Table 3 when analyzing only late Nazi party entries (1929-33). In Table C.2, we use logs of the dependent variable - entry rates into the NSDAP - and of the main explanatory variable. We find nearly-identical results, except in the case of military associations, which are now insignificant. The coefficient on nonmilitary associations is also insignificant, but only an epsilon below standard cutoff levels. Once we add controls, the overall association density and the nonmilitary associations are highly significant. The greater robustness of the effect of non-military associations actually strengthens our results; it suggests that the channel that is supportive of our proposed argument - focused social capital as 
such, and not the presence of nationalistic and militarist attitudes - is driving our results.

Table C.1: Late entries

Dependent variable: Late Nazi Party entry rates, 1929-33

\begin{tabular}{|c|c|c|c|c|c|c|}
\hline & $(1)$ & (2) & (3) & $\overline{(4)}$ & (5) & (6) \\
\hline${ }_{A S S O C_{\text {all }}}$ & $\begin{array}{c}0.326^{* * *} \\
(3.42)\end{array}$ & & & $\begin{array}{c}0.328^{* * * *} \\
(3.74)\end{array}$ & & \\
\hline ASSOC $_{\text {non-military }}$ & & $\begin{array}{l}0.190^{* *} \\
(2.05)\end{array}$ & & & $\begin{array}{l}0.252^{* *} \\
(2.34)\end{array}$ & \\
\hline ASSOC $C_{\text {military }}$ & & & $\begin{array}{c}0.396^{* * *} \\
(3.30)\end{array}$ & & & $\begin{array}{l}0.325^{* *} \\
(2.42)\end{array}$ \\
\hline Share Catholics & & & & $\begin{array}{c}-0.347^{* * *} \\
(-4.09)\end{array}$ & $\begin{array}{c}-0.369^{* * *} \\
(-3.72)\end{array}$ & $\begin{array}{c}-0.331^{* * *} \\
(-3.67)\end{array}$ \\
\hline $\ln ($ рор) & & & & $\begin{array}{l}0.155^{*} \\
(1.77)\end{array}$ & $\begin{array}{c}0.272^{* * * *} \\
(2.81)\end{array}$ & $\begin{array}{c}0.160^{* *} \\
(2.01)\end{array}$ \\
\hline Share Blue-collar & & & & $\begin{array}{c}-0.267^{* * *} \\
(-3.66)\end{array}$ & $\begin{array}{c}-0.305^{* * *} \\
(-3.57)\end{array}$ & $\begin{array}{c}-0.256^{* * *} \\
(-3.61)\end{array}$ \\
\hline Observations & 103 & 82 & 97 & 100 & 79 & 94 \\
\hline Adjusted $R^{2}$ & 0.098 & 0.024 & 0.148 & 0.288 & 0.266 & 0.319 \\
\hline
\end{tabular}


Table C.2: Log specification

Dependent variable: Natural log of Nazi Party entry rates, 1925-33

\begin{tabular}{|c|c|c|c|c|c|c|}
\hline & $(1)$ & $(2)$ & (3) & (4) & (5) & (6) \\
\hline $\ln \left(A S S O C_{\text {all }}\right)$ & $\begin{array}{c}0.368^{* * * *} \\
(4.01)\end{array}$ & & & $\begin{array}{c}0.407^{* * *} \\
(3.71)\end{array}$ & & \\
\hline $\ln \left(\mathrm{ASSOC}_{\text {non-military }}\right)$ & & $\begin{array}{c}0.235^{* * *} \\
(2.67)\end{array}$ & & & $\begin{array}{c}0.326^{* * *} \\
(2.95)\end{array}$ & \\
\hline $\ln \left(A S S O C_{\text {military }}\right)$ & & & $\begin{array}{c}0.344^{* * *} \\
(2.94)\end{array}$ & & & $\begin{array}{c}0.261^{* *} \\
(2.09)\end{array}$ \\
\hline Share Catholics & & & & $\begin{array}{c}-0.311^{* * *} \\
(-3.67)\end{array}$ & $\begin{array}{c}-0.391^{* * *} \\
(-4.09)\end{array}$ & $\begin{array}{c}-0.366^{* * *} \\
(-4.00)\end{array}$ \\
\hline $\ln ($ pop) & & & & $\begin{array}{c}0.205^{* *} \\
(2.01)\end{array}$ & $\begin{array}{c}0.296^{* * *} \\
(2.94)\end{array}$ & $\begin{array}{l}0.143^{*} \\
(1.70)\end{array}$ \\
\hline Share Blue-collar & & & & $\begin{array}{c}-0.221^{* * *} \\
(-2.99)\end{array}$ & $\begin{array}{c}-0.253^{* * *} \\
(-2.95)\end{array}$ & $\begin{array}{c}-0.240^{* * *} \\
(-3.31)\end{array}$ \\
\hline Observations & 103 & 82 & 97 & 100 & 79 & 94 \\
\hline Adjusted $R^{2}$ & 0.127 & 0.043 & 0.109 & 0.294 & 0.289 & 0.290 \\
\hline
\end{tabular}

In Table C.3, we use median regressions, where we analyze the conditional median instead of the conditional mean by minimizing the absolute deviations from the expected value, and not of the square of deviations. Coefficients are large, and significance levels are high; results are largely identical with those derived in the baseline estimation results under OLS. 
Table C.3: Median regression results

Dependent variable: Nazi Party entry rates, 1925-33

\begin{tabular}{|c|c|c|c|c|c|c|}
\hline & $(1)_{x, x}$ & $(2)$ & (3) & $(4)$ & (5) & (6) \\
\hline ASSOC $_{\text {all }}$ & $\begin{array}{c}0.347^{* * *} \\
(5.04)\end{array}$ & & & $\begin{array}{c}0.389^{* * *} \\
(6.53)\end{array}$ & & \\
\hline ASSOC $_{\text {non-military }}$ & & $\begin{array}{l}0.228^{*} \\
(1.96)\end{array}$ & & & $\begin{array}{c}0.317^{* * *} \\
(3.78)\end{array}$ & \\
\hline ASSOC $C_{\text {military }}$ & & & $\begin{array}{c}0.360^{* * *} \\
(3.22)\end{array}$ & & & $\begin{array}{c}0.358^{* * *} \\
(4.76)\end{array}$ \\
\hline Share Catholics & & & & $\begin{array}{c}-0.188^{* * *} \\
(-3.39)\end{array}$ & $\begin{array}{c}-0.293^{* * *} \\
(-4.16)\end{array}$ & $\begin{array}{c}-0.278^{* * * *} \\
(-4.00)\end{array}$ \\
\hline $\ln ($ pop) & & & & $\begin{array}{c}0.225^{* * *} \\
(3.61)\end{array}$ & $\begin{array}{c}0.310^{* * *} \\
(3.77)\end{array}$ & $\begin{array}{l}0.163^{* *} \\
(2.28)\end{array}$ \\
\hline Share Blue-collar & & & & $\begin{array}{c}-0.100^{*} \\
(-1.75)\end{array}$ & $\begin{array}{l}-0.104 \\
(-1.43)\end{array}$ & $\begin{array}{c}-0.142^{* *} \\
(-2.01)\end{array}$ \\
\hline Observations & 103 & 82 & 97 & 100 & 79 & 94 \\
\hline
\end{tabular}

In Figure C.1, we show the effect of a unit increase in association density on NS entry rates, by quantile of the dependent variable. The size of the coefficient rises for very low and very high rates of entry, and stays similar for most of the range of values.

Finally, we include observations for towns with populations below 5,000 inhabitants. These are excluded in the baseline because of the potential for noise to overwhelm the estimation. The noise arises for two reasons. First, it reflects the difficulty of finding NS members in any one locale in the digitized subset of membership records. Second, as the size of a city falls, the need to formally constitute clubs, associations, and societies declines - in small towns, many inhabitants know each other personally. Table C.4 gives the results for the full sample with up to 111 towns and cities. The coefficients for military and nonmilitary organizations in the specifications without controls are now smaller and 
insignificant. However, once we include the set of controls, the coefficients are highly significant and very similar to the baseline.

Table C.4: Including results for towns with less than $\mathbf{5 , 0 0 0}$ inhabitants Dependent variable: Nazi Party entry rates, 1925-33

\begin{tabular}{|c|c|c|c|c|c|c|}
\hline & (1) & (2) & (3) & (4) & (5) & (6) \\
\hline ASSOC $_{\text {all }}$ & $\begin{array}{l}0.217^{*} \\
(1.66)\end{array}$ & & & $\begin{array}{c}0.422^{* * *} \\
(4.81)\end{array}$ & & \\
\hline ASSOC $_{\text {non-military }}$ & & $\begin{array}{l}0.116 \\
(1.28)\end{array}$ & & & $\begin{array}{c}0.290^{* *} \\
(2.64)\end{array}$ & \\
\hline ASSOC $_{\text {military }}$ & & & $\begin{array}{l}0.061 \\
(0.46)\end{array}$ & & & $\begin{array}{c}0.309^{* * *} \\
(3.29)\end{array}$ \\
\hline Share Catholics & & & & $\begin{array}{c}-0.329^{* * *} \\
(-4.02)\end{array}$ & $\begin{array}{c}-0.381^{* * *} \\
(-3.91)\end{array}$ & $\begin{array}{c}-0.360^{* * *} \\
(-4.13)\end{array}$ \\
\hline $\ln (\mathrm{pop})$ & & & & $\begin{array}{c}0.177^{* *} \\
(2.03)\end{array}$ & $\begin{array}{c}0.262^{* * *} \\
(2.69)\end{array}$ & $\begin{array}{l}0.146{ }^{*} \\
(1.90)\end{array}$ \\
\hline Share Blue-collar & & & & $\begin{array}{c}-0.241^{* * *} \\
(-3.33)\end{array}$ & $\begin{array}{c}-0.274^{* * *} \\
(-3.16)\end{array}$ & $\begin{array}{c}-0.239^{* * *} \\
(-3.34)\end{array}$ \\
\hline Observations & 111 & 89 & 105 & 101 & 79 & 95 \\
\hline Adjusted $R^{2}$ & 0.038 & 0.002 & -0.006 & 0.332 & 0.275 & 0.326 \\
\hline
\end{tabular}




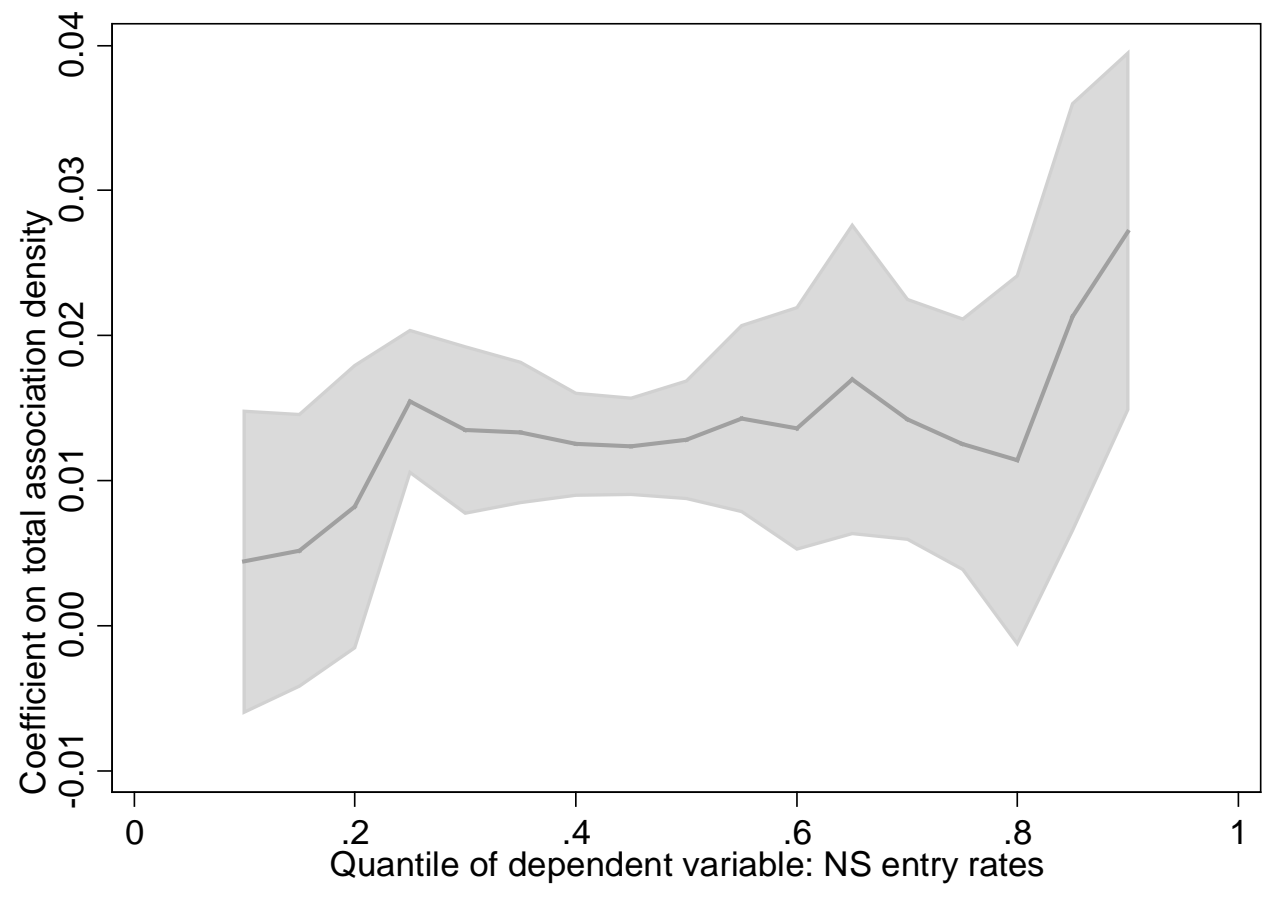

Figure C.1: Quantile regression graph - Effect of unit increase in association density on NS entry rates, by quantile of the dependent variable

\section{Appendix D: Relaxing Instrument Exogeneity}

In this appendix, we describe our implementation of the generalized IV approach in Conley, Hansen and Rossi (2012), which allows for a direct effect of the instrument on the outcome variable. Since our analysis includes two instruments, we first compute their principal components. This combines our instruments into one variable (note that linear combinations of valid instruments remain valid instruments - c.f. Bai and Ng (2010); Winkelried and Smith (2011)). 
We first confirm that the IV regressions with the principal component as instrument yield very similar results as those presented in the paper. ${ }^{33}$ We then assume, following Conley et al. (2012), that the (potential) direct effect of the instrument on party entry, $\gamma$, is uniformly distributed in an interval $[0, \delta]$, with $\delta>0$. By varying $\delta$, we identify the threshold at which the second-stage coefficient on (instrumented) association density becomes insignificant at the 10\% level. Figure D.1 shows the results for our main specification, using the standard controls and $A S S O C_{\text {all }}$ as measure of association density. We identify a threshold of $\hat{\delta}=0.0085$. That is, as long as the direct effect of our instruments on party entry is smaller than 0.0076 , our second stage is still significant at the $10 \%$ level.

To gauge magnitudes, we compare this to the overall reduced-form effect of the principal component instrument on party entry, which is 0.014 (we also include the standard controls in this regression). Therefore, the direct effect of the instruments on party entry would have to be about one-half of the overall effect to render our IV results insignificant.

${ }^{33}$ For example, for the main specification based on all associations (column 6 in Table 5), we obtain a second-stage coefficient on ASSOC $_{\text {all }}$ of 1.198 with an Anderson-Rubin p-value of 0.0001 . 


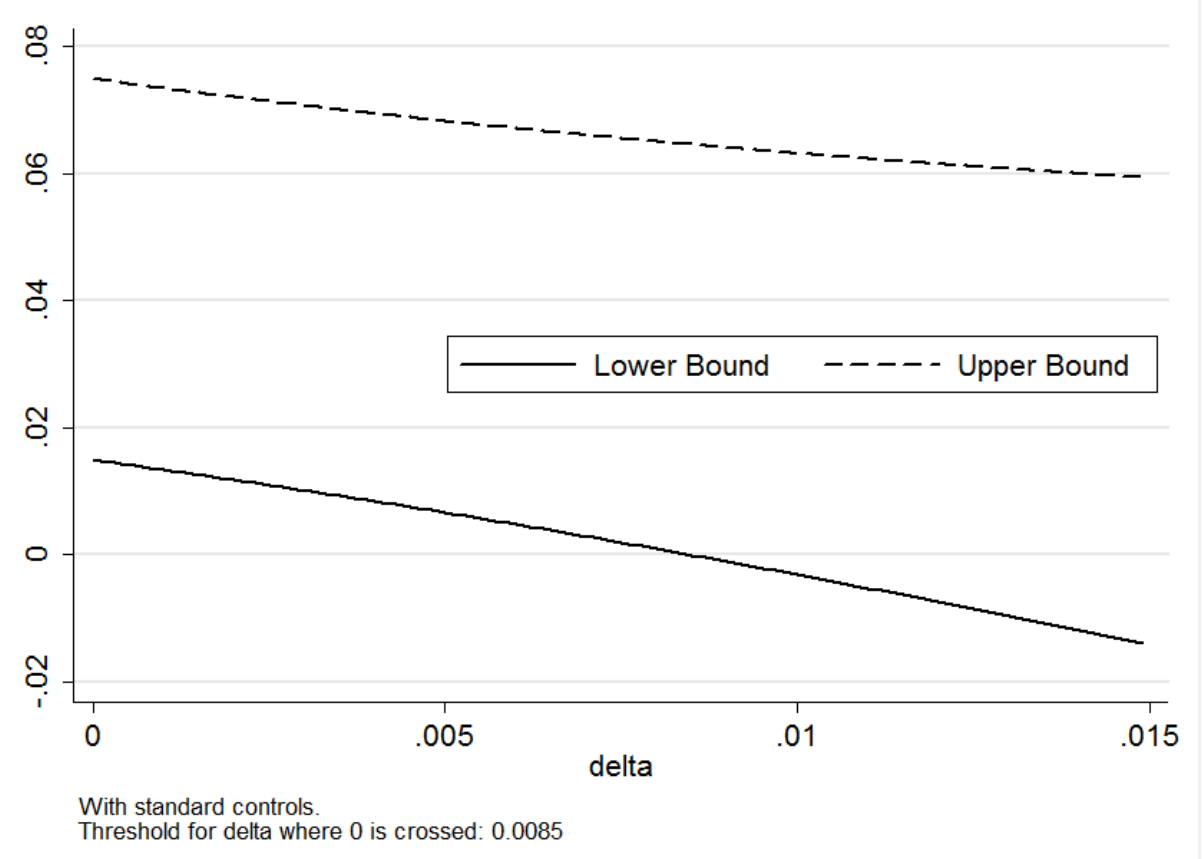

Figure D.1: 90\% Confidence interval of main effect (of association density on party entry), by direct effect of instruments

\section{Appendix E: Cities in Directory Sample}

1. Ahaus

2. Ahrweiler

3. Altona

4. Amberg

5. Apolda

6. Backnang

7. Bad Langensalza

8. Baden Baden

9. Bayreuth

10. Beckum

11. Bernau

12. Biberach

13. Bietigheim

14. Bingen

15. Bochum

16. Bonn

17. Borken

18. Bretten

19. Buchen

20. Buer

21. Calau
38. Ettlingen

39. Euskirchen

40. Freiburg

41. Gelsenkirchen

42. Gera

43. Gifhorn

44. Gladbeck

45. Godesberg

46. Goettingen

47. Gotha

48. Guben

49. Hannover

50. Heilbronn

51. Heiligenstadt

52. Herford

53. Herne

54. Hohenlimburg

55. Ilmenau

56. Ingolstadt

57. Iserlohn

58. Jena
76. Menden

77. Moers

78. Moessingen

79. Muehlheim (Ruhr)

80. Muenchen

81. Muenster

82. Neckarsulm

83. Neuss

84. Neustadt an der Haardt

85. Northeim

86. Pforzheim

87. Plauen

88. Potsdam

89. Ravensburg

90. Recklinghausen

91. Rendsburg

92. Rottenburg a. N.

93. Rudolstadt

94. Schwaebisch Hall

95. Schweinfurt 
22. Castrop-Rauxel

23. Celle

24. Chemnitz

25. Coburg

26. Cottbus

27. Delmenhorst

28. Detmold

29. DuerrmenzMuehlacker

30. Duesseldorf

31. Duisburg

32. Ebingen

33. Eisenach

34. Erfurt

35. Essen

36. Hagen

37. Hamburg
59. Kiel

60. Kleve

61. Konstanz

62. Krefeld

63. Lahnstein

64. Lehrte

65. Luckau

66. Ludwigsburg

67. Luebbenau

68. Luebeck

69. Mainz

70. Mannheim

71. Memmingen

72. Nuernberg

73. Oberhausen

74. Paderborn

75. Passau
96. Senftenberg

97. Singen

98. Speyer

99. Steinfurt

100.Tailfingen

101.Tuebingen

102.Tuttlingen

103.Uelzen

104.Villingen

105.Wanne-Eickel

106.Wattenscheid

107.Weimar

108. Weissenfels

109. Westerstede

110.Wiesbaden

111.Worms 